\title{
The Aerosol Characterization from Polarimeter and Lidar (ACEPOL) airborne field campaign
}

\author{
Kirk Knobelspiesse ${ }^{1}$, Henrique M. J. Barbosa ${ }^{2,11}$, Christine Bradley ${ }^{3}$, Carol Bruegge $^{3}$, Brian Cairns $^{4}$, \\ Gao Chen ${ }^{5}$, Jacek Chowdhary ${ }^{4,6}$, Anthony Cook ${ }^{5}$, Antonio Di Noia ${ }^{8}$, Bastiaan van Diedenhoven ${ }^{4,7}$, \\ David J. Diner ${ }^{3}$, Richard Ferrare ${ }^{5}$, Guangliang Fu ${ }^{9}$, Meng Gao ${ }^{1,10}$, Michael Garay ${ }^{3}$, Johnathan Hair ${ }^{5}$, \\ David Harper $^{5}$, Gerard van Harten ${ }^{3}$, Otto Hasekamp ${ }^{8}$, Mark Helmlinger ${ }^{3}$, Chris Hostetler ${ }^{5}$, \\ Olga Kalashnikova ${ }^{3}$, Andrew Kupchock ${ }^{1,10}$, Karla Longo De Freitas ${ }^{1,16}$, Hal Maring ${ }^{11}$, \\ J. Vanderlei Martins ${ }^{12}$, Brent McBride ${ }^{12}$, Matthew McGill ${ }^{1}$, Ken Norlin ${ }^{13}$, Anin Puthukkudy ${ }^{12}$, \\ Brian Rheingans $^{3}$, Jeroen Rietjens ${ }^{9}$, Felix C. Seidel ${ }^{3,11}$, Arlindo da Silva ${ }^{1}$, Martijn Smit ${ }^{9}$, \\ Snorre Stamnes ${ }^{5}$, Qian Tan ${ }^{14}$, Sebastian Val ${ }^{3}$, Andrzej Wasilewski ${ }^{4}$, Feng Xu ${ }^{15}$, Xiaoguang Xu ${ }^{12}$, and \\ John Yorks ${ }^{1}$ \\ ${ }^{1}$ NASA Goddard Space Flight Center, Greenbelt, MD, USA \\ ${ }^{2}$ Instituto de Física, Universidade de Sāo Paulo, Sāo Paulo, Brazil \\ ${ }^{3}$ Jet Propulsion Laboratory, California Institute of Technology, Pasadena, CA, USA \\ ${ }^{4}$ NASA Goddard Institute for Space Studies, New York, NY, USA \\ ${ }^{5}$ NASA Langley Research Center, Hampton, VA, USA \\ ${ }^{6}$ Department of Applied Physics and Applied Mathematics, Columbia University, New York, NY, USA \\ ${ }^{7}$ Earth Institute, Columbia University, New York, NY, USA \\ ${ }^{8}$ Department of Physics and Astronomy, University of Leicester, Leicestershire, UK \\ ${ }^{9}$ SRON Netherlands Institute for Space Research, Utrecht, the Netherlands \\ ${ }^{10}$ Science Systems and Applications, Inc., Greenbelt, MD, USA \\ ${ }^{11}$ NASA Headquarters, Washington, D.C., USA \\ ${ }^{12}$ Department of Physics, University of Maryland, Baltimore County, Baltimore, MD, USA \\ ${ }^{13}$ NASA Armstrong Flight Research Center, Edwards, CA, USA \\ ${ }^{14}$ NASA Ames Research Center, Moffett Field, CA, USA \\ ${ }^{15}$ School of Meteorology, University of Oklahoma, Norman, OK, USA \\ ${ }^{16}$ Universities Space Research Association, Columbia, MD, USA
}

Correspondence: Kirk Knobelspiesse (kirk.knobelspiesse@nasa.gov)

Received: 25 March 2020 - Discussion started: 27 April 2020

Revised: 19 July 2020 - Accepted: 31 July 2020 - Published: 14 September 2020

\begin{abstract}
In the fall of 2017, an airborne field campaign was conducted from the NASA Armstrong Flight Research Center in Palmdale, California, to advance the remote sensing of aerosols and clouds with multi-angle polarimeters (MAP) and lidars. The Aerosol Characterization from Polarimeter and Lidar (ACEPOL) campaign was jointly sponsored by NASA and the Netherlands Institute for Space Research (SRON). Six instruments were deployed on the ER-2 high-altitude aircraft. Four were MAPs: the Airborne Hyper Angular Rainbow Polarimeter (AirHARP), the Airborne Multiangle SpectroPolarimetric Imager (AirMSPI), the Airborne Spectrometer for Planetary EXploration (SPEX airborne), and the Research Scanning Polarimeter (RSP). The remainder were lidars, including the Cloud Physics Lidar (CPL) and the High Spectral Resolution Lidar 2 (HSRL-2). The southern California base of ACEPOL enabled observation of a wide variety of scene types, including urban, desert, forest, coastal ocean, and agricultural areas, with clear, cloudy, polluted, and pristine atmospheric conditions. Flights were performed in coordination with satellite overpasses and ground-based observations, including the Groundbased Multiangle SpectroPolarimetric Imager (GroundMSPI), sun photometers, and a surface reflectance spectrometer.
\end{abstract}


ACEPOL is a resource for remote sensing communities as they prepare for the next generation of spaceborne MAP and lidar missions. Data are appropriate for algorithm development and testing, instrument intercomparison, and investigations of active and passive instrument data fusion. They are freely available to the public. The DOI for the primary database is https://doi.org/10.5067/SUBORBITAL/ACEPOL2017/DATA001 (ACEPOL Science Team, 2017), while for AirMSPI it is https://doi.org/10.5067/AIRCRAFT/AIRMSPI/ACEPOL/RADIANCE/ELLIPSOID_V006 and https://doi.org/10.5067/AIRCRAFT/AIRMSPI/ACEPOL/RADIANCE/TERRAIN_V006 (ACEPOL AirMSPI 75 Science Team, 2017a, b). GroundMSPI data are at https://doi.org/10.5067/GROUND/GROUNDMSPI/ACEPOL/RADIANCE_v009 (GroundMSPI Science Team, 2017). Table 3 lists further details of these archives. This paper describes ACEPOL for potential data users and also provides an outline of requirements for future field missions with similar objectives.

\section{Introduction}

Aerosols, clouds, and their interactions are the largest source of uncertainty in estimates of the radiative forcing of the Earth. Reducing this uncertainty requires global observations to act as constraints for studies of the role of aerosols and clouds in a changing climate (Boucher et al., 2013). While existing passive orbital sensors show observational skill, they are limited in their consistency and underdetermined for retrieval of the relevant geophysical parameters (Mishchenko et al., 2004). In other words, the remote sensing retrieval solutions are often nonunique, and they require the use of constraints in the form of, for example, aerosol models, which may or may not represent geophysical reality. For this reason, the 2007 Decadal Survey of the National Research Council recommended to the National Aeronautics and Space Administration (NASA) the creation of the Aerosol-CloudEcosystems (ACE) mission, with the stated goal to reduce climate forcing uncertainty of aerosol-cloud interactions and to better understand ocean ecosystem carbon dioxide uptake (National Research Council, 2007). This recommendation led to the ACE pre-formulation mission study (da Silva et al., 2019). This study (2008-2018) was devoted to technological and scientific developments to address aerosol-cloud climate forcing uncertainty along with improved observations of ocean color to better characterize ocean biology. Designs for an ocean color instrument were enhancements of previous ocean color satellite instruments, such as the Sea-viewing Wide Field-of-view Sensor (SeaWiFS; McClain et al., 2004). These prototypes were, in part, developed and tested by deploying airborne instruments on high-altitude aircraft. Thus, airborne field campaigns were a key component of the ACE pre-formulation study.

ACEPOL was one of several field campaigns supported by ACE, with the specific objective of testing lidar and multi-angle polarimeter (MAP) instruments in a variety of conditions. Such instruments reduce aerosol and cloud climate forcing uncertainties by accurately determining aerosol and cloud optical and microphysical properties and vertical distribution. They are, however, diverse in their mea- surement characteristics, retrieval approaches, and capability (Weitkamp, 2006; Kokhanovsky et al., 2015; Dubovik et al., 2019). Six of these instruments were installed on the ER2 aircraft, which, because of its capability for high-altitude, long-range flights, provides an ideal platform for exploring measurement concepts of relevance to ACE. Two were lidars: the Cloud Physics Lidar (CPL), and the High Spectral Resolution Lidar 2 (HSRL-2), while the remaining four instruments were MAPs: the Airborne Hyper Angular Rainbow Polarimeter (AirHARP), the Airborne Multiangle SpectroPolarimetric Imager (AirMSPI), the Airborne Spectrometer for Planetary EXploration (SPEX airborne) and the Research Scanning Polarimeter (RSP). See Table 1 for a summary of the characteristics of these instruments and Sect. 3 for more detail.

In addition to supporting ACE, an ACEPOL objective was to provide a calibration reference for the Cloud-Aerosol $\mathrm{Li}$ dar with Orthogonal Polarization (CALIOP) instrument on the Cloud-Aerosol Lidar and Infrared Pathfinder Satellite Observations (CALIPSO) mission (Winker et al., 2009). This was performed with coordinated flights along the satellite ground track at the time of overpass. A coordinated underflight of the Cloud-Aerosol Transport System (CATS) orbital lidar (McGill et al., 2015) was also conducted. The third sponsor of the ACEPOL field campaign was the Netherlands Institute for Space Research (SRON), partly funded through the NWO/NSO project ACEPOL (ALW-GO/16-09), to further advance aerosol measurement capabilities from space and the technological development of the SPEX airborne instrument in particular.

ACEPOL consisted of nine flights from the Armstrong Flight Research Center (AFRC) in Palmdale, California, in October and November 2017. AFRC is the home base of the ER-2 aircraft and has excellent supporting facilities. Furthermore, it is within range of a variety of types of scenes, oceans off the California coast, urban areas in Los Angeles, intensive agriculture in the California central valley, forests in the Sierra Nevada mountains, and the high desert in California, Nevada, and Arizona. Aerosol and clouds within these regions are similarly varied. An additional benefit is 
Table 1. Airborne instrument characteristics as implemented on the ER-2 during ACEPOL.

\begin{tabular}{|c|c|c|c|c|c|}
\hline Polarimeters & Principal investigator & Spectral band centers & View angles & Spatial sampling & Spatial resolution \\
\hline AirHARP & J. Vanderlei Martins, UMBC & $\begin{array}{l}4: \quad 440, \quad 550, \quad 670, \\
870 \mathrm{~nm}\end{array}$ & $\begin{array}{l}670 \mathrm{~nm}: 60 \text { in } \pm 57^{\circ} \\
\text { fore to aft of nadir, } \\
\text { other channels: } 20 \text { in } \\
\pm 57^{\circ} \text { fore to aft of } \\
\text { nadir }\end{array}$ & $\begin{array}{l} \pm 47^{\circ} \text { cross-track field } \\
\text { of view (FOV), tar- } \\
\text { geted sampling mode } \\
(\sim 42.9 \mathrm{~km} \text { at ground) }\end{array}$ & $\begin{array}{l}\text { Gridded to } 2000 \text { pixels } \\
\text { per latitude degree, na- } \\
\text { tive value: } \sim 55 \mathrm{~m}\end{array}$ \\
\hline AirMSPI & David J. Diner, JPL & $\begin{array}{l}8: \quad 355, \quad 380, \quad 445, \\
470^{*}, 555,660^{*}, 865^{*}, \\
935 \mathrm{~nm}\end{array}$ & $\begin{array}{l}\text { Varies with targeting } \\
\text { mode, } 10 \text { or } 15 \text { angle } \\
\text { pseudo-stare or contin- } \\
\text { uous sweep }\end{array}$ & $\begin{array}{l} \pm 15^{\circ} \text { cross-track FOV } \\
(9 \mathrm{~km} \text { at ground }), \text { tar- } \\
\text { geted sampling mode }\end{array}$ & $\begin{array}{l}10 \mathrm{~m} \text { at ground for } \\
\text { pseudo-stare, } 25 \mathrm{~m} \text { for } \\
\text { continuous sweep }\end{array}$ \\
\hline RSP & Brian Cairns, NASA GISS & $\begin{array}{lrr}9: & 410.3, & 555, \\
469.1, \quad 670, & 863.5, \\
960, \quad 1593.5, & 1880, \\
2263.5 \mathrm{~nm} & \end{array}$ & $\begin{array}{l}120 \text { from } 45^{\circ} \text { fore to } \\
65^{\circ} \text { aft of nadir }\end{array}$ & $\begin{array}{l}\text { Single pixel }(280 \mathrm{~m}) \text {, } \\
\text { continuous sample }\end{array}$ & $\begin{array}{l}280 \mathrm{~m} \text {, partial succes- } \\
\text { sive pixel overlap }\end{array}$ \\
\hline SPEX airborne & Otto Hasekamp, SRON & $\begin{array}{l}400-800 \mathrm{~nm}, \quad \sim 2 \mathrm{~nm} \\
\text { resolution for inten- } \\
\text { sity, } 10-40 \mathrm{~nm} \text { for } \\
\text { polarization }\end{array}$ & $\begin{array}{l}9: \pm 57^{\circ}, \pm 42^{\circ}, \pm 28^{\circ} \\
\pm 14 \text {, and } 0^{\circ}\end{array}$ & $\begin{array}{l}6^{\circ} \text { cross-track, continu- } \\
\text { ous sample }\end{array}$ & $\begin{array}{l}\text { Native resolution } \\
\sim 200 \mathrm{~m} \text { (nadir) }-1 \mathrm{~km} \\
\left( \pm 57^{\circ}\right) .\end{array}$ \\
\hline Lidars & & Backscatter channels & Extinction channels & Horizontal resolution & Vertical resolution \\
\hline CPL & Matthew McGill, NASA GSFC & $355,532,1064 \mathrm{~nm}$ & - & $\sim 200 \mathrm{~m}$ & $30 \mathrm{~m}$ \\
\hline HSRL-2 & Chris Hostetler, NASA LaRC & $355,532,1064 \mathrm{~nm}$ & $355,532 \mathrm{~nm}$ & $1-2 \mathrm{~km}$ & $15 \mathrm{~m}$ \\
\hline
\end{tabular}

* AirMSPI has polarization sensitivity for 470,660 , and $865 \mathrm{~nm}$ only; all other polarimeters have polarization sensitivity in all spectral channels.

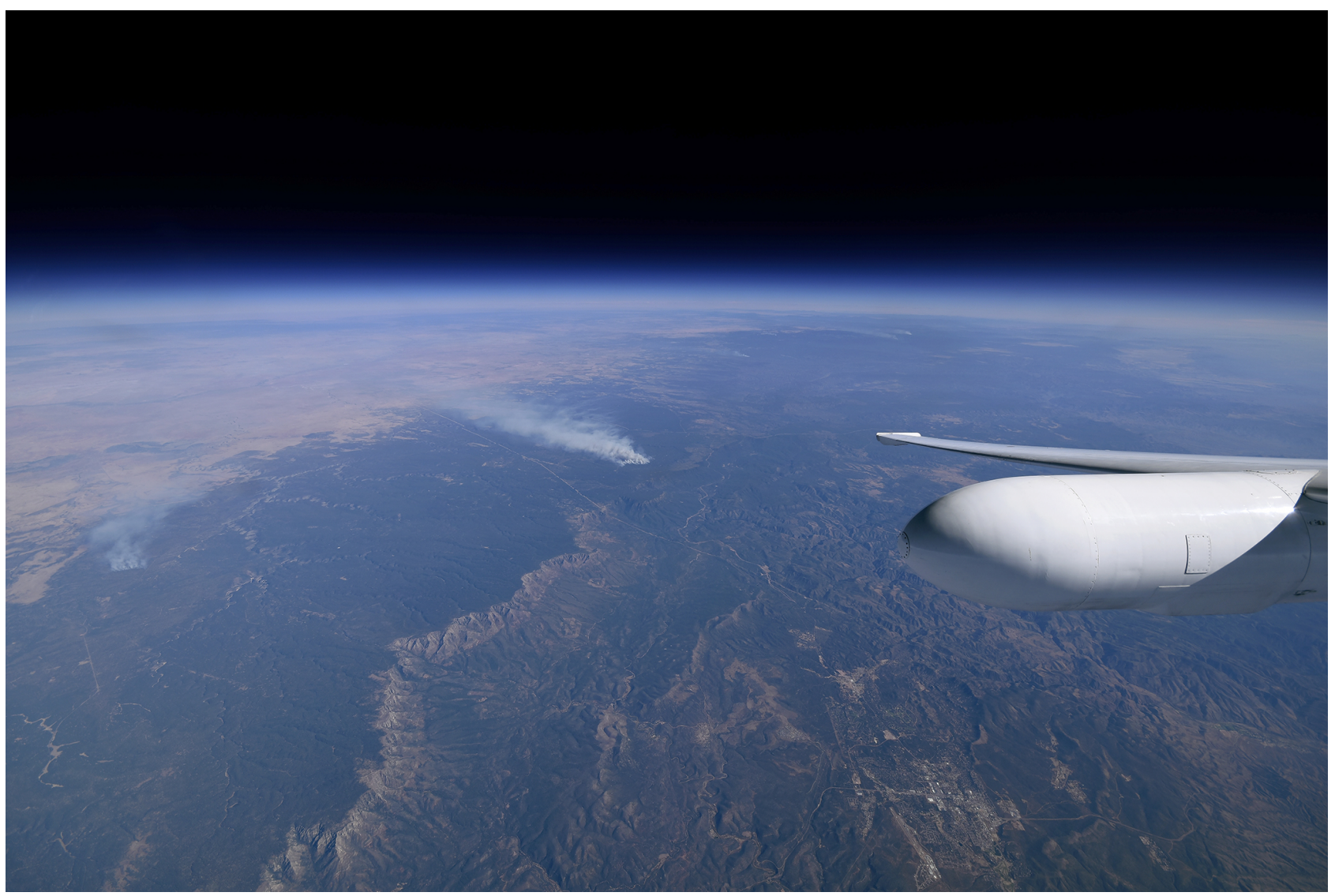

Figure 1. Photograph from the ER-2 of smoke from prescribed burns in Kaibab National Forest in Arizona on 9 November 2017. Credit: NASA/Stu Broce. 
the accessibility of many ground validation sites, in particular the aerosol observations of the Aerosol Robotic Network (AERONET; Holben et al., 1998), and desert salt pans such as Rosamond Dry Lake for which comprehensive surface reflectance characterization allows vicarious calibration of airborne sensors. Figure 1 is a pilot's photograph from the cockpit of the ER-2, which illustrates the unique, high-altitude vantage point of the aircraft. Deployment of an instrument on this aircraft is a close analog for the space environment and observation conditions. Figures 2 and 3 show the ER-2 on the ground with a portion of the ACEPOL team and the ACEPOL emblem, respectively. The latter indicates the position of the remote sensing instruments on board the aircraft, with two on the fuselage and two in each wing pod.

Consistent with NASA's policy on data collection and availability, ACEPOL data are publicly available (see Data availability). The purpose of this article is to document the conditions under which these data were collected to aid their use by the scientific community and to describe initial efforts by the ACEPOL team to analyze and compare results. As such, Sect. 2 describes the ACEPOL measurement objectives, while Sect. 3 covers instrument specifics. Section 4 chronicles the field deployment and identifies successful observations of targets described in Sect. 2. Section 5 discusses the value of ACEPOL for various current and planned missions, while Sect. 7 concludes.

\section{Objectives}

The overall objectives of the ACEPOL field campaign, as is described below, were to test new observation systems, develop new algorithms, and validate orbital observations. For that reason, a wide range of observation conditions were desired. This differs from field campaigns investigating specific processes for the purpose of broader scientific understanding. The goals of this campaign instead focused on improvement of measurement techniques, instrument calibration, and algorithm development. All flights started and ended in southern California, enabling flights over urban, rural, mountainous, desert, coastal, and deep ocean regions in a variety of atmospheric conditions. To better organize flight planning, the ACEPOL measurement objectives were condensed into a list of prioritized targets, as described in Table 2 and below.

Target types fell into four broad categories: calibration, geolocation, validation, and targets of opportunity. Calibration targets $(1 \mathrm{a}, 1 \mathrm{~b}$, and $1 \mathrm{c})$ were meant to provide spatially uniform observations with which radiometric and polarimetric measurements between multi-angle polarimeters can be compared. A similar intercomparison was performed during the Polarimeter Definition Experiment (PODEX) between the RSP and AirMSPI instruments (Knobelspiesse et al., 2019). Intercomparison can now be performed with those instruments plus AirHARP and SPEX airborne. Such intercomparisons can confirm measurement uncertainty es- timates and identify calibration problems. Different scene types are useful for intercomparison: cloud-free ocean observations (1a) provide low-reflectance, potentially highly polarized measurements, while land scenes can have high reflectance but moderate to low polarization. Cloud scenes provide high reflectance and low polarization. Intercomparison requires accurate geolocation, so minimizing scene heterogeneity and atmospheric variation is important. Furthermore, scenes with distinct features, such as coastlines, were targeted to provide a geolocation reference (1d). Validation targets are used to test the geophysical products retrieved by the airborne sensors against similar observations on the ground ( $2 \mathrm{a}, 2 \mathrm{~b}$ ), by other field campaigns (2c), and by satellites (3a, $3 b)$. Targets of opportunity are intended for algorithm development and represent infrequently observed or difficult scenes. Finally, it should be noted that the target number designation roughly indicates priority. Low numbered targets are of highest priority and are generally organized such that targets supporting validation or calibration of radiometric quantities have the greatest precedence, followed by validation of geophysical products derived from such observations, and then special cases and difficult scenes (targets of opportunity).

Most of the highest-priority targets were observed successfully during ACEPOL, although conditions precluded observation of uniform marine stratocumulus cloud decks (target 1c) and most cases of high aerosol loads. The latter was highly unusual for this part of the world, as California's San Joaquin Valley and the Los Angeles metropolitan area are known for typically high aerosol loads. The solution was to overfly controlled forest fire burns farther afield in Arizona. Attempted coordination with the Coupled Air-Sea Processes and EM Ducting Research (CASPER) east (Wang et al., 2018) field campaign was unfortunately not possible because of scheduling difficulty and weather. Serendipitously, one flight overlapped with a flight by the Alpha Jet Atmospheric Experiment (AJAX), which carried a payload of atmospheric gas sensors. High aerosol loads over the ocean (4a) were not observed, but low aerosol load overflights of an AERONET site (2b) on a platform off Long Beach, CA, have become the basis for several analysis papers (e.g., Fu et al., 2020; Gao et al., 2020). Another important accomplishment was the successful overflight of Rosamond Dry Lake from multiple headings while a ground-based team characterized the spectral reflectance of the lake bed. This was used to vicariously adjust the AirMSPI calibration and serves as a reference for other measurements as well.

Furthermore, the value of ACEPOL observations exceeds these initial objectives. For example, polarimetric observations of land surfaces may be useful for assessment of bidirectional reflectance distribution function (BRDF) and bidirectional polarization distribution function (BPDF) models even by other instruments, and observations over the ocean can be used to help develop ocean remote sensing algorithms (see Sect. 5.4 for more details on the latter). 


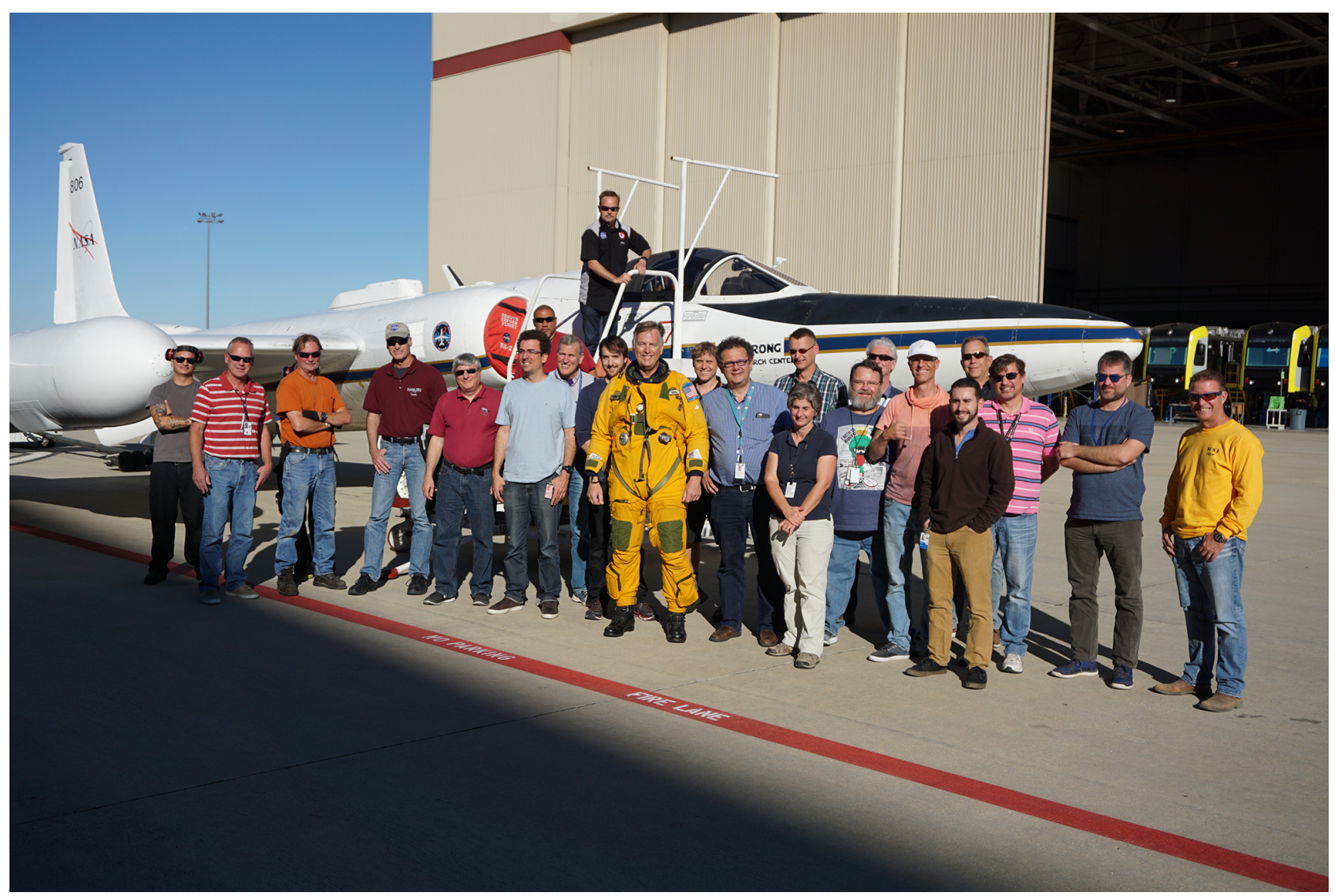

Figure 2. A portion of the ACEPOL team with the NASA ER-2 at the NASA Armstrong Flight Research Center in Palmdale, California.

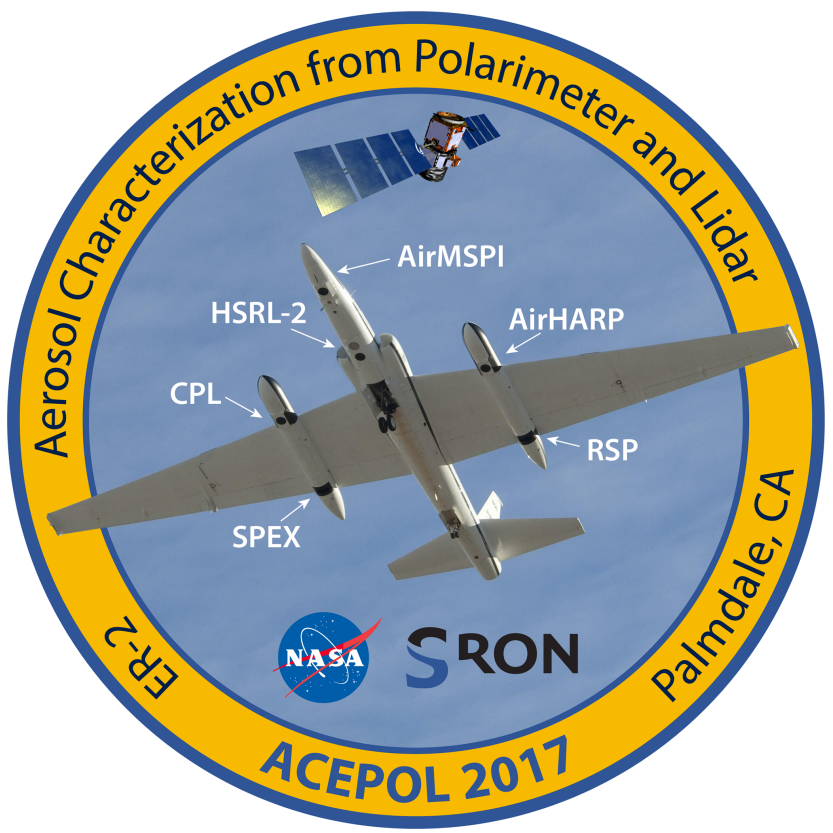

Figure 3. The ACEPOL field campaign emblem, which also shows the positions of instruments on board the ER-2 aircraft.

\subsection{The Aerosol Cloud Ecosystems (ACE) mission study}

ACE pre-formulation study activities included defining mission requirements, advancing algorithms and instrument technical readiness by convening science workshops, developing mission design white papers, and supporting new or augmenting otherwise planned field campaigns (see https: //acemission.gsfc.nasa.gov, last access: 3 September 2020). Technological development and scientific utilization of three classes of instruments were supported by the ACE study. These instruments included cloud and precipitation radars, atmospheric profiling aerosol and cloud lidars, and MAPs. Lidars and MAPs are the most relevant for aerosol remote sensing and were deployed in early 2013 for PODEX (Diner et al., 2013; Alexandrov et al., 2015; Van Harten et al., 2018; Knobelspiesse et al., 2019) and in ACEPOL during the fall of 2017. In some ways, PODEX can be considered a precursor to ACEPOL. Both used the high-altitude ER-2 aircraft based at AFRC, flew in a variety of conditions, and deployed AirMSPI, CPL, and RSP (among other instruments). PODEX also deployed the Passive Aerosol and Cloud Suite (PACS), an earlier version of AirHARP. ACEPOL offers a larger collection of more mature instruments, notably the SPEX airborne 
Table 2. Prioritized ACEPOL measurement targets. In this table, low aerosol loading indicates a mid-visible aerosol optical depth (AOD) less than 0.1, moderate AOD between 0.1 and 0.2, and high AOD greater than 0.2.

\begin{tabular}{|c|c|c|c|}
\hline Target & Description & Achieved? & Dates (2017) \\
\hline $1 \mathrm{a}$ & Calibration over ocean with no clouds or aerosols & Yes & 23 Oct, 25 Oct, 7 Nov \\
\hline $1 \mathrm{~b}$ & Calibration over land with no clouds or aerosols & Yes & 25 Oct \\
\hline $1 \mathrm{c}$ & Calibration over spatially uniform cloud deck & Partially & 1 Nov \\
\hline $1 \mathrm{~d}$ & Geolocation using coastlines with no clouds & Yes & 23 Oct, 25 Oct, 26 Oct, 7 Nov \\
\hline $1 \mathrm{e}$ & Coordinated CALIOP/CALIPSO or CATS underflight & Yes & 19 Oct, 26 Oct, 7 Nov, 9 Nov \\
\hline $2 \mathrm{a}$ & Validation with AERONET with medium to high aerosol loading & Yes & $\begin{array}{l}23 \text { Oct, } 25 \text { Oct, } 26 \text { Oct, } 1 \text { Nov, } \\
7 \text { Nov, } 9 \text { Nov }\end{array}$ \\
\hline $2 b$ & Validation with AERONET with low aerosol loading & Yes & $\begin{array}{l}23 \text { Oct, } 25 \text { Oct, } 26 \text { Oct, } 1 \text { Nov, } \\
7 \text { Nov, } 9 \text { Nov }\end{array}$ \\
\hline $2 \mathrm{c}$ & Validation against CASPER field campaign & No & $\begin{array}{l}\text { None, but one overlap with an } \\
\text { AJAX flight on } 9 \text { Nov }\end{array}$ \\
\hline $3 a$ & Satellite intercomparison for aerosol retrievals & Yes & 23 Oct, 27 Oct, 1 Nov \\
\hline $3 b$ & Satellite intercomparison for cloud retrievals & Partially & 9 Nov \\
\hline $4 \mathrm{a}$ & Targets of opportunity: high aerosol loads over ocean & No & - \\
\hline $4 \mathrm{~b}$ & Target of opportunity: high aerosol loads over land & Yes & 27 Oct, 1 Nov, 7 Nov \\
\hline $4 \mathrm{c}$ & Targets of opportunity: multiple aerosol layers & No & - \\
\hline 5 & Targets of opportunity: aerosol above cloud & No & - \\
\hline 6 & Targets of opportunity: high aerosol loads over urban surfaces & No & _ \\
\hline 7 & Targets of opportunity: marine stratocumulus clouds far from land & No & - \\
\hline 8 & Targets of opportunity: broken clouds far from land & No & _ \\
\hline 9 & Targets of opportunity: low clouds over land & Yes & 1 Nov, 3 Nov \\
\hline 10 & Targets of opportunity: cirrus clouds & Yes & $\begin{array}{l}19 \text { Oct, } 23 \text { Oct, } 3 \text { Nov, } 7 \text { Nov, } 9 \\
\text { Nov }\end{array}$ \\
\hline
\end{tabular}

and AirHARP polarimeters and the HSRL-2 lidar. ACEPOL offers an opportunity to also intercompare single-instrument and synergistic algorithms involving lidars and MAPs.

\subsection{Cloud-Aerosol Lidar and Infrared Pathfinder Satellite Observations (CALIPSO) mission validation}

Airborne measurements of particulate backscatter and extinction have been important for assessing CALIOP $532 \mathrm{~nm}$ (Powell et al., 2009; Rogers et al., 2011) and $1064 \mathrm{~nm}$ (Vaughan et al., 2010, 2019) level 1 attenuated backscatter profiles, level 2 aerosol optical depth (AOD) retrievals (Rogers et al., 2014), aerosol classification methodology (Burton et al., 2013), cirrus cloud properties (Yorks et al., 2011), and combined active (CALIOP) passive (Moderate Resolution Imaging Spectroradiometer, MODIS) retrievals of aerosol extinction profiles (Burton et al., 2010). Using airborne measurements to evaluate CALIOP aerosol backscatter measurements avoids uncertainties caused by systematic errors, spatial inhomogeneities, and distortions associated with using ground-based lidar measurements for such validation (Gimmestad et al., 2017). Consequently, ACEPOL also collected measurements under the CALIOP on flights conducted on 26 October and 7 and 9 November and under the CATS sensor on 19 October.

\subsection{Netherlands Institute for Space Research (SRON) studies}

The ACEPOL campaign served several SRON objectives related to the improvement of MAP instrument performance and aerosol retrievals and investigation of algorithm development for aerosol retrievals using both polarimeter and lidar measurements. Specifically, the SPEX airborne instrument deployed during ACEPOL is a prototype of the SPEXone instrument that is contributed to the upcoming NASA PACE mission, due to be launched in late 2022. Validation of the SPEX airborne level 1 data products (radiance and degree of linear polarization, DoLP) during ACEPOL serves to identify possible improvements to be implemented in the SPEXone instrument that is to be contributed to NASA's Plankton-Aerosol-Cloud-ocean Ecosystem (PACE; Werdell et al., 2019) mission. The PACE spacecraft will fly three instruments in low Earth orbit. The primary instrument is a UV-NIR (ultraviolet and near infrared) imaging spectrometer with additional shortwave infrared (SWIR) bands, while two MAPs will be contributed: SPEXone and HARP-2 (see Sect. 3.1.1 for a description of the airborne prototype of that instrument). Additionally, ACEPOL provides a test dataset for level 2 algorithm development for SPEXone on PACE. The SRON participation in ACEPOL was funded by the Netherlands Organization for Scientific Research (NWO) and the Netherlands Space Office (NSO). 


\section{Observations}

\subsection{Polarimeters}

\subsubsection{The Airborne Hyper Angular Rainbow Polarimeter (AirHARP)}

AirHARP is a wide field-of-view imaging polarimeter designed for characterization of cloud and aerosol optical properties. AirHARP is an amplitude-splitting polarimeter: light entering the front lens is decomposed into three orthogonal linear polarization states $\left(0,45\right.$, and $\left.90^{\circ}\right)$ by a modified threeway Phillips prism. Each polarization state is imaged by a unique detector array, so the first three parameters of the Stokes vector $(I, Q$, and $U)$ are retrieved at pixel level by combining co-located information from all three detectors. Stripe filters on the detectors define 120 distinct along-track viewing angles across the four HARP wavelengths (spectral widths): 440 (14), 550 (12), 670 (18), and $870(38) \mathrm{nm}$, across a total swath of $\pm 57^{\circ}\left( \pm 47^{\circ}\right)$ along track (cross track). A total of 60 of these angles are at $670 \mathrm{~nm}$, specifically designed for studying the structure of the polarized cloudbow. The high angular resolution (roughly $2^{\circ}$ ) enables AirHARP to measure the cloudbow structure at all individual pixels. The remaining three wavelengths have 20 angles each for characterization of aerosols. Figure $4 \mathrm{a}$ shows an illustration of the sampling scheme applied by the HARP polarimeters, where each along-track viewing angle of the instrument produces a full push-broom image. The figure also shows an example of data collected during the ACEPOL campaign, its second deployment. The instrument's maiden field campaign was the Lake Michigan Ozone Study (LMOS) in 2017 (McBride et al., 2020). For ACEPOL, AirHARP collected data over defined targets, as the processing speed of the onboard data acquisition system precluded continuous data collection.

AirHARP is an aircraft demonstration for the HARP CubeSat instrument, a stand-alone satellite that was successfully launched on 19 February 2020 from the International Space Station (ISS) conducting Earth observations for a yearlong mission. A third member of the HARP family is the HARP2 sensor, which will provide global coverage in $2 \mathrm{~d}$, as part of the NASA PACE mission due to launch no earlier than 2022 (Werdell et al., 2019).

AirHARP Level 0 ACEPOL data are corrected, reconstructed, geolocated, and calibrated in the Hyper-Angular Image Processing Pipeline (HIPP) Level 1B algorithm. These data products are gridded to a horizontal resolution of 2000 pixels per latitude degree and packaged into HDF5 files for distribution in the ACEPOL data archive. A Level 2 aerosol retrieval algorithm has been implemented using the Generalized Retrieval for Aerosol and Surface Properties (GRASP) scheme (Dubovik et al., 2011; Puthukkudy et al., 2020). Figure 4d shows the AOD map retrieved using AirHARP measurements and the GRASP inversion algorithm for a smoke scene in Fig. 4c. The magnitude and spatial variability of retrieved AirHARP AOD are in good agreement with collocated lidar (i.e., HSRL-2) observations (Puthukkudy et al., 2020) and are also consistent with the AOD retrieved from AirSPEX and RSP instruments (Fu et al., 2020). Cloud droplet size distribution retrievals are implemented using a traditional parametric fit to Mie scattering curves for liquid water droplets (McBride et al., 2020). Retrievals of ice cloud characteristics, aerosols above clouds, ocean and surface reflectance properties, and atmospheric correction are also important potential uses of HARP data.

\subsubsection{The Airborne Multiangle SpectroPolarimetric Imager (AirMSPI)}

The Airborne Multiangle SpectroPolarimetric Imager (AirMSPI; Diner et al., 2013b) is push-broom imaging camera used for the characterization of atmospheric aerosols and clouds. In addition to radiometric channels, AirMSPI employs photoelastic modulators (PEMs) to enable accurate measurements of the degree and angle of linear polarization (Diner et al., 2010; van Harten et al., 2018). These polarimetric data help discriminate between different aerosol particle types, which is crucial to improving our understanding on climate and air quality. The instrument flies aboard NASA's high-altitude ER-2 aircraft and acquires Earth imagery with $\sim 10 \mathrm{~m}$ spatial resolution across a $9 \mathrm{~km}$ wide swath. Radiance data are obtained at 355, 380, 445, 470, 555, 660, 865 , and $935 \mathrm{~nm}$. The polarimetric channels at 470,660 , and $865 \mathrm{~nm}$ report both radiances and the linear polarization Stokes components $Q$ and $U$. AirMSPI is a precursor to the future Multi-Angle Imager for Aerosols (MAIA) satellite instrument (see Sect. 5.3), which will be used to improve our understanding of the health risks associated with airborne particulate matter.

The AirMSPI camera is mounted on a motorized singleaxis gimbal to enable multiple views of a science target from different along-track view angles. The number of views and specific set of angles for each observing sequence are programmable prior to flight. While approaching the target in a straight and level flight line, the pilot presses one of three buttons to start the corresponding multi-angle acquisition sequence. Figure 5 shows example imagery of the sequences used during the ACEPOL campaign. All three modes begin and end with views of the onboard dark target and polarization validator light source.

AirMSPI observed a total of 24 targets in the nine-angle step-and-pseudostare mode, 32 targets in the 15-angle mode, and 209 continuous-sweep images. AirMSPI L1B2 geolocated radiometric and polarimetric data and quick looks are available as noted in the Data availability section. For a further analysis and comparison with other MAPs and lidars during ACEPOL, see Fu et al. (2020). 
(a)

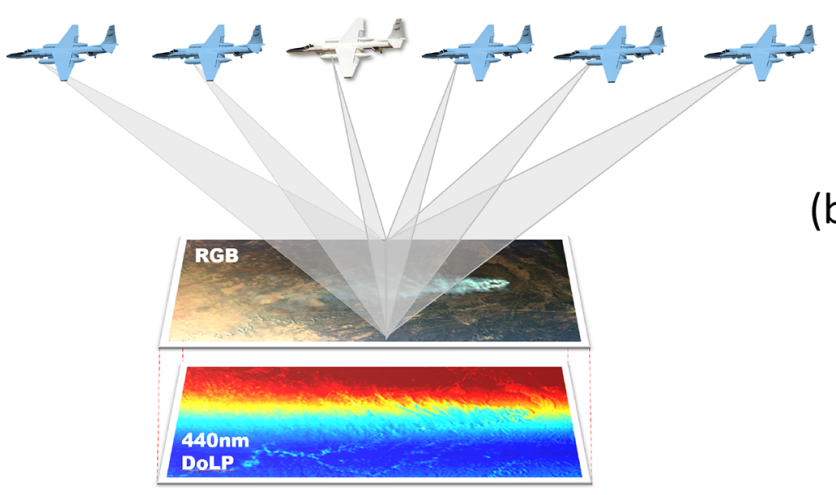

(c)

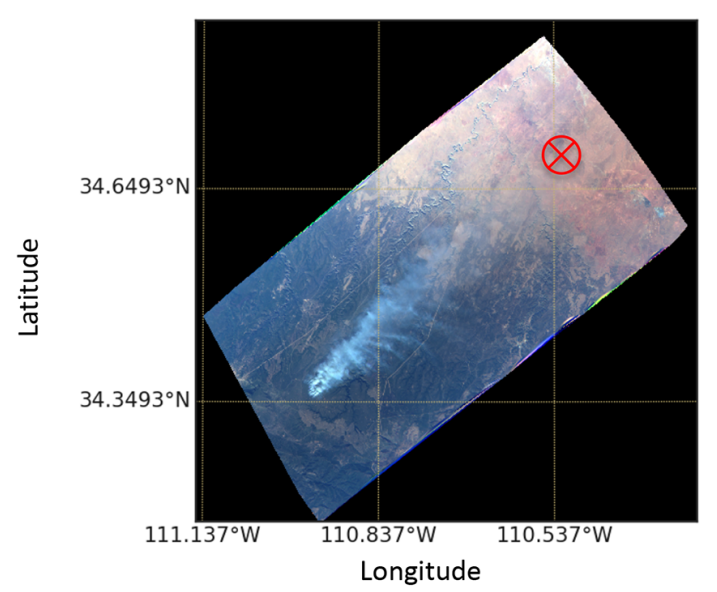

AirHARP geo projected nadir RGB composite Image on 09-November-2017 T19:30:55 UTC (b)

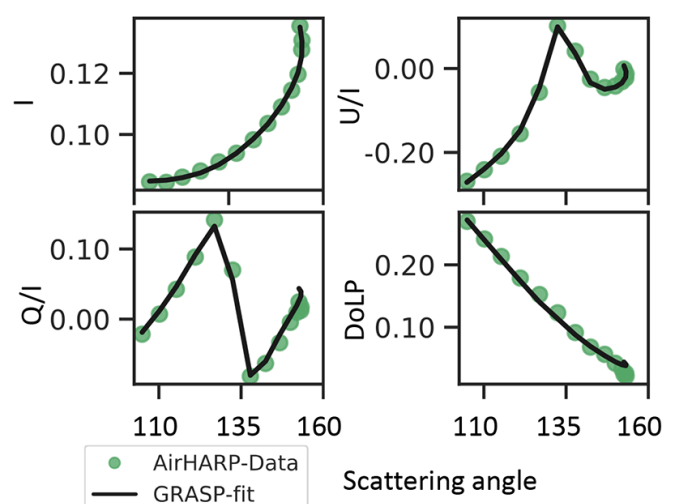

AirHARP measured data for a single pixel from the scene in (c) marked by a cross wire

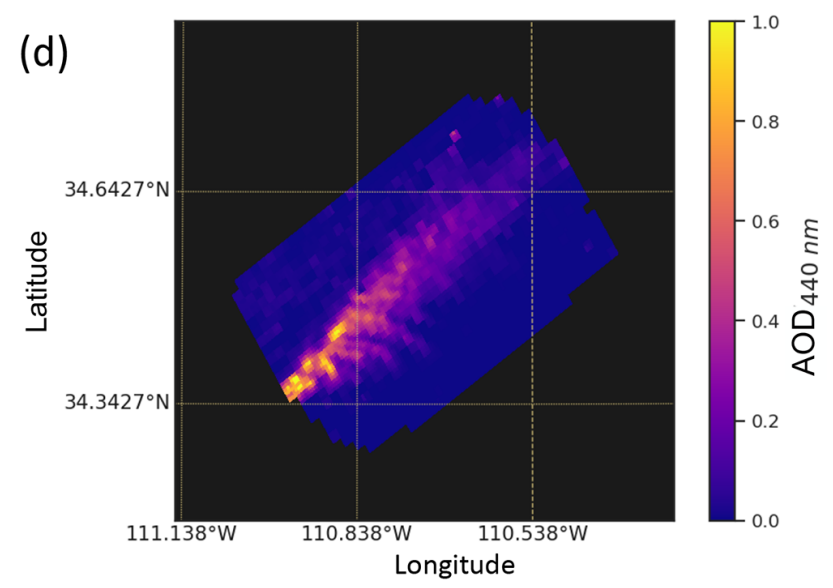

$\mathrm{AOD}_{440 \mathrm{~nm}}$ map from AirHARP GRASP retrievals for the scene on 09-November-2017T19:30:55 UTC

Figure 4. (a) Illustration of the AirHARP sampling scheme applied during the ACEPOL experiment. Each along-track viewing angle produces a full push-broom image. Six along-track viewing angles are shown in the subplot. HARP has up to 60 along-track viewing angles for $670 \mathrm{~nm}$ and up to 20 viewing angles for other wavelengths; (b) AirHARP measured (solid circles) $I, Q / I, U / I$, and DoLP for a pixel marked by red cross wire in (c), plotted as a function of scattering angle and GRASP forward model fit for the variables of the same pixel (solid black lines); (c) RGB composite image of a smoke scene collected on 9 November 2017 at 19:31 UTC; (d) map of aerosol optical depth (AOD) at $440 \mathrm{~nm}$ retrieved for the same scene using AirHARP measurements and the GRASP inversion algorithm.

\subsubsection{The Research Scanning Polarimeter (RSP)}

A pair of RSP instruments (denoted RSP1 and RSP2; the latter was used in ACEPOL) have been deployed on more than 25 field missions in the last 20 years. The RSP is an airborne multi-angle and multispectral polarimeter that continuously scans in the aircraft along-track direction. During a complete scanner rotation, a total of 205 samples, each with a $0.8^{\circ}$ (14 mrad) field of view, are collected. The 205 samples include 152 views between $60^{\circ}$ forward and aft of the normal to its baseplate, 10 samples viewing an internal dark reference, and 43 samples through an Earth-viewing polarization scrambler. Samples are obtained by a rotating polarizationcompensated mirror assembly with six bore-sighted telescopes, to simultaneously obtain nine Stokes parameter spectral bands. Each telescope uses a Wollaston prism to split the incoming intensity into two spatially separated orthogonally polarized components, which are then further split and passed through dichroic filters, defined by the spectral bandpass: (full width at half maximum bandwidths in parentheses) 410.3 (30), 469.1 (20), 555.0 (20), 670.0 (20), 863.5 (20), 960.0 (20), 1593.5 (60), 1880.0 (90), and 2263.5 (120) $\mathrm{nm}$. On the ER-2, the un-vignetted viewing angle range is from $65^{\circ}$ aft to $45^{\circ}$ forward, for a total of 120 samples. The single nadir ground pixel size from an altitude of $20 \mathrm{~km}$ is $280 \mathrm{~m}$, and successive pixels partially overlap.

RSP2 was calibrated in the Airborne Sensor Facility at NASA Ames Research Center before and after ACEPOL. Radiometric calibration was stable to within roughly $1 \%$ for all bands, except for $410.3 \mathrm{~nm}$, where a $4 \%$ decrease in radiometric throughput was observed (polarimetric calibration 


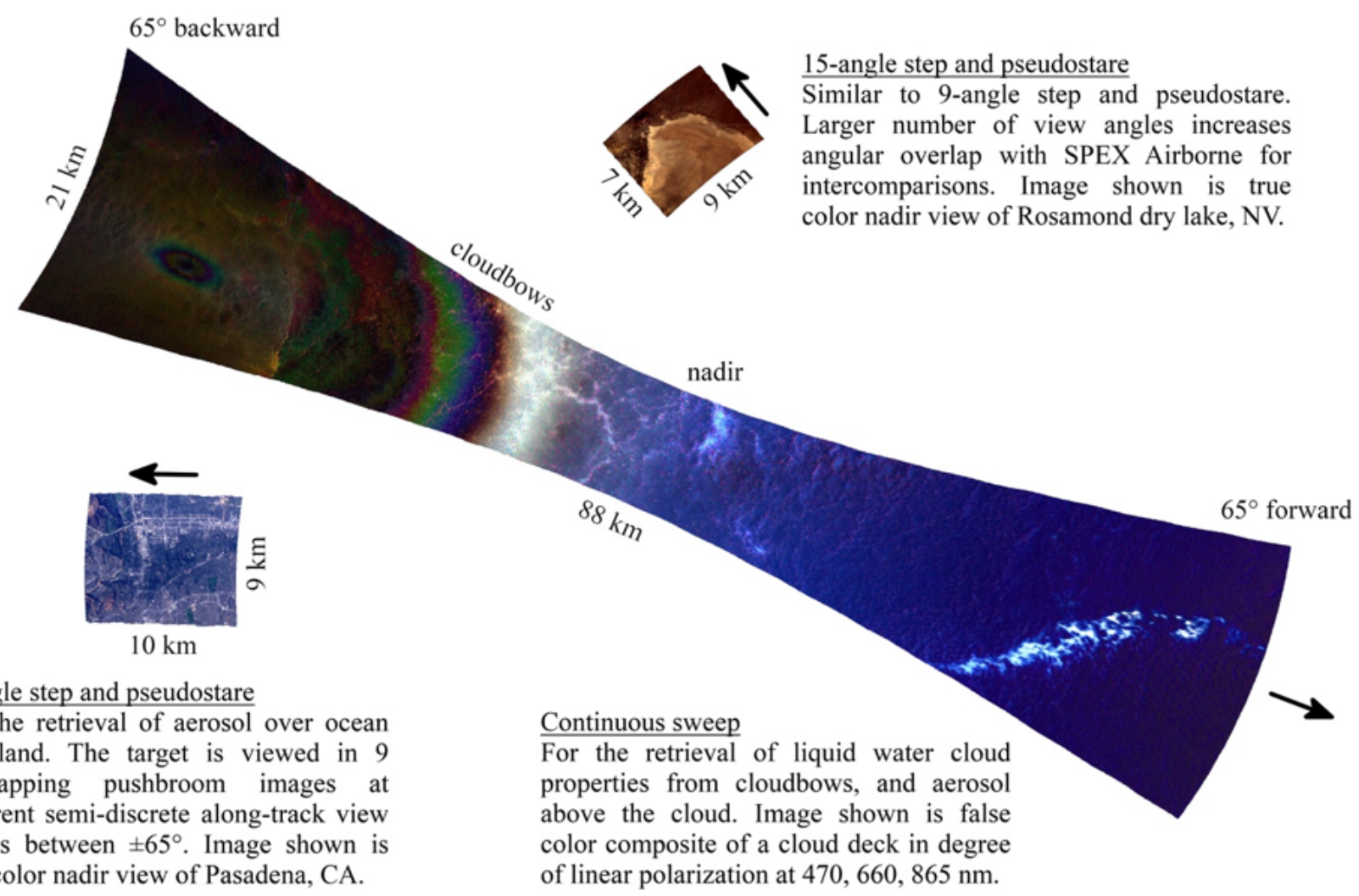

Figure 5. AirMSPI quick looks for the three different multi-angle observation modes. Aircraft flight direction is indicated by arrows.

was stable to within $\sim 0.1 \%$ ). Data processing to level $1 \mathrm{~b}$ (calibrated and geolocated at-sensor measurements) consists of dark subtraction for each scan and application of calibration coefficients to generate Stokes parameters, together with the geolocation of each viewing angle sample. Processing from level $1 \mathrm{~b}$ to level $1 \mathrm{c}$ consists of collocating the different viewing angles about a defined altitude, either at the ground or at cloud-top if a cloud is present. The latter requires cloud identification and a cloud top height estimate (Sinclair et al., 2017). Level 2 processing of cloudy scenes is split between water and ice clouds. Water cloud retrievals include cloud optical depth and standard bi-spectral droplet size estimates (Platnick et al., 2016), as well as both parametric (Alexandrov et al., 2012b) and nonparametric (Alexandrov et al., 2012a) droplet size distribution estimates that use polarization (Alexandrov et al., 2018). Most clouds observed during ACEPOL were low-level water clouds, but when ice clouds were detected, cloud optical depth, particle size, and particle shape/roughness retrievals (Van Diedenhoven et al., 2012, 2013; Van Diedenhoven, 2018) were retrieved. Level 2 processing for aerosol retrievals uses the Microphysical Aerosol Properties from Polarimetry (MAPP) algorithm (Stamnes et al., 2018). The MAPP land surface model consists of a Fresnel reflectance with shadowing for the polarized reflectance (Waquet et al., 2009) together with a RossThick (Ross, 1981; Roujean et al., 1992) LiSparse (Li and Strahler, 1992) kernel model (Wanner et al., 1995), similar to that used for operational processing of MODIS land surface products (Schaaf et al., 2002). RSP was operational for all ACEPOL flights, and data are available at the ACEPOL data archive (see Data availability section). Example RSP observations of a liquid phase cloud are shown in Fig. 6.

\subsubsection{The Airborne Spectrometer for Planetary EXploration (SPEX airborne)}

The SPEX airborne instrument (Smit et al., 2019) employs the spectral modulation technique (Snik et al., 2009), in which the degree and angle of linear polarization are encoded in a modulation of the radiance spectrum as a function of wavelength. This modulation is achieved by placing a set of dedicated optical components (quarter wave retarder, multiple order retarder) in front of the telescope. The resulting two light beams contain a modulation pattern as a function of wavelength (out of phase with each other) that enter a spectrometer and are focused on a detector. Radiance measurements are obtained between 400 and $800 \mathrm{~nm}$ at the spectral resolution of the spectrometer $(\sim 2 \mathrm{~nm})$, while for DoLP the spectral resolution is determined by the modulation period, which is conservatively estimated at $10 \mathrm{~nm}$ at $400 \mathrm{~nm}$ and $40 \mathrm{~nm}$ at $800 \mathrm{~nm}$. 

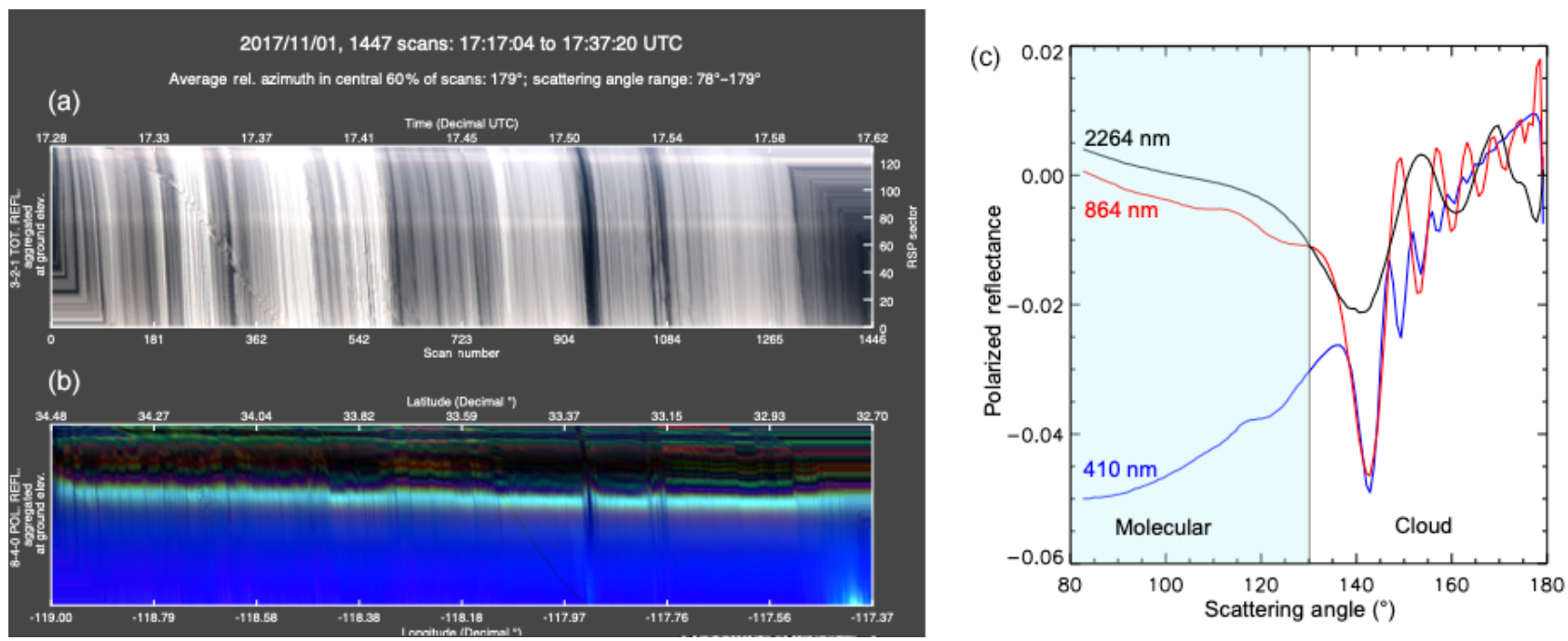

Figure 6. RSP quick look image (a, b) from 1 November 2017. The vertical dimension represents view angle and the horizontal dimension scan number (time elapsed). Panel (c) is a single level 1C scan corresponding to scan 1235 at (a, b). It shows the signature of cloud bows at large scattering angles $\left(135-180^{\circ}\right.$ ) and molecular (Rayleigh) scattering for $410 \mathrm{~nm}$ at scattering angles smaller than $130^{\circ}$. Retrieved droplet size parameters are effective radius of $11.5 \mu \mathrm{m}$ and effective variance of 0.008 .

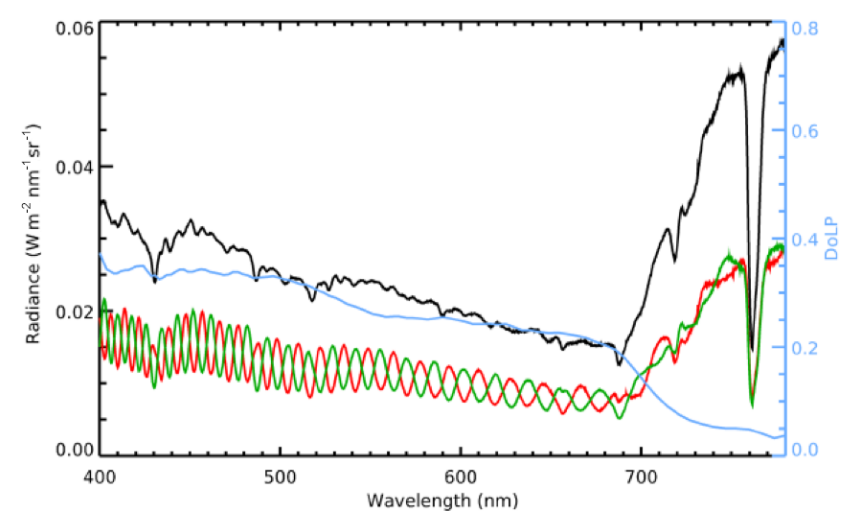

Figure 7. Example of SPEX airborne measurements over vegetation, for radiance (black line) and DoLP (blue line) as function of wavelength. The modulated spectra from which radiance and DoLP are derived are shown in green and red.

An example of a SPEX airborne radiance and DoLP measurement obtained during ACEPOL is shown in Fig. 7.

SPEX airborne has nine view ports that are projected on one detector, at angles $\left( \pm 57, \pm 42, \pm 28, \pm 14\right.$, and $\left.0^{\circ}\right)$. The SPEX airborne cross-track swath is $6^{\circ}$. The data processing from level 0 (detector counts) to level $1 \mathrm{~b}$ (calibrated and geolocated radiance and DoLP values) consists of the following steps: dark image subtraction, spectral extraction and line-ofsight annotation, wavelength annotation, spectral alignment of the two modulated spectra, radiometric correction, demodulation, and geolocation. Next, data of the different view ports are all aggregated on the same spatial grid, yielding the level $1 \mathrm{C}$ data product, currently computed at $1 \mathrm{~km} \times 1 \mathrm{~km}$ spatial resolution.

For level 2 processing (Fu et al., 2020), the SPEX airborne team has focused on aerosol retrievals, building further on the SRON aerosol retrieval algorithm previously used for POLDER-3 processing (Hasekamp et al., 2011; Lacagnina et al., 2015, 2017) and groundSPEX (van Harten et al., 2014; di Noia et al., 2015). The algorithm has been extended from a bimodal retrieval scheme to multimode retrieval scheme for an arbitrary number of modes (Fu and Hasekamp, 2018). For processing ACEPOL data, a setup with five modes has been used, where for each mode the aerosol column number is retrieved corresponding to a set of fine- and coarse-mode spectrally varying refractive indices, the fraction of spherical particles (Dubovik et al., 2006), and the aerosol layer height. SPEX airborne data have been processed using 16 discrete wavelengths between 450 and $750 \mathrm{~nm}$. Wavelengths less than $450 \mathrm{~nm}$ and greater than $750 \mathrm{~nm}$ are excluded because of lower data quality. SPEX airborne was operational for all ACEPOL flights, and data are available at the ACEPOL data archive.

\subsection{Lidars}

\subsubsection{The Cloud Physics Lidar (CPL)}

The Cloud Physics Lidar (CPL) is a nadir-pointing, multiwavelength $(355,532,1064 \mathrm{~nm})$ elastic backscatter lidar that measures vertical profiles of cloud and aerosol properties (McGill et al., 2002). CPL has participated in numerous field campaigns since its first deployment in 2000 on the ER-2, often in tandem with the other remote sensing instruments 
involved in ACEPOL. Raw CPL data are calibrated by normalizing the 355,532 , and $1064 \mathrm{~nm}$ signals to the Rayleigh (molecular) backscatter between 15 and $18 \mathrm{~km}$, creating vertical profiles of the total attenuated backscatter (McGill et al., 2007). CPL data products retrieved from the calibrated backscatter include vertical profiles of depolarization ratio, particulate backscatter coefficient, and particulate extinction coefficients, as well as layer properties such as top and base altitudes, aerosol type, and optical depth (Yorks et al., 2011; Hlavka et al., 2012).

CPL data products, with vertical resolution of $30 \mathrm{~m}$ and $1 \mathrm{~s}$ frequencies ( $\sim 200 \mathrm{~m}$ horizontal resolution), enable a wide range of applications including the analysis of cloud properties (McGill et al., 2004; Bucholtz et al., 2010; Yorks et al., 2011; Alexandrov et al., 2015), as well as aerosol and dust properties (McGill et al., 2003; Nowottnick et al., 2011; Wu et al., 2016). CPL data from ACEPOL are fully processed and data products are available at the ACEPOL data repository. However, an electronics controller failed in the CPL laser during the second flight of the campaign. The cause of this failure was not immediately apparent, and there was no time to take the instrument out of service during the ACEPOL campaign. Thus, the ACEPOL CPL data products after the first flight are nonstandard, as they required more averaging, sometimes as much as $10 \mathrm{~s}$ ( $2 \mathrm{~km}$ horizontal), and removal of some data at specific wavelengths due to poor quality. Nevertheless, data are useful for validation of CALIPSO (McGill et al., 2007; Yorks et al., 2011; Hlavka et al., 2012) and CATS data (Yorks et al., 2016; Pauly et al., 2019.)

\subsubsection{The High Spectral Resolution Lidar (HSRL-2)}

HSRL-2 is the second-generation airborne High Spectral Resolution Lidar developed at NASA Langley Research Center. Like the first-generation HSRL-1 (Hair et al., 2008), HSRL-2 independently measures aerosol backscatter and extinction $(532 \mathrm{~nm})$ using the HSRL technique, aerosol backscatter $(1064 \mathrm{~nm})$ using the standard backscatter technique (Müller et al., 2014; Sawamura et al., 2017), and aerosol depolarization at both wavelengths. HSRL-2 adds measurements of aerosol backscatter and extinction at $355 \mathrm{~nm}$ using the HSRL technique as well as measurements of aerosol depolarization at $355 \mathrm{~nm}$. These HSRL-2 measurements are used to compute AOD as well as the aerosol extinction / backscatter ratio ("lidar ratio") at 355 and $532 \mathrm{~nm}$. Rogers et al. (2009) evaluated the HSRL extinction coefficient profiles and found that the HSRL extinction profiles are within the systematic errors of airborne in situ measurements at visible wavelengths. Derived products include, first, estimates of planetary boundary layer heights which use the vertically resolved profile measurements of aerosol backscatter to derive aerosol mixed-layer heights during the daytime (Scarino et al., 2014). Second, aerosol classification uses an algorithm to interpret the information about aerosol physical properties indicated by the HSRL-2 aerosol intensive pa- rameters to qualitatively infer aerosol type (Burton et al., 2012). HSRL-2 measurements have also been used to retrieve height-resolved parameters such as aerosol effective radius and concentrations (number, surface, volume) (Müller et al., 2014; Sawamura et al., 2017).

HSRL-2 has been deployed on various NASA aircraft for both NASA and DOE field missions (Berg et al., 2016; Sawamura et al., 2017; Burton et al., 2018). During ACEPOL, HSRL-2 operated autonomously from the NASA ER-2 aircraft. When operated from the ER-2, the nominal HSRL-2 aerosol backscatter profiles are reported at a vertical resolution of $15 \mathrm{~m}$ and a horizontal (temporal) resolution of $1-2 \mathrm{~km}$ (10 s). Aerosol depolarization ratios at all three wavelengths are reported at the same resolutions. For ACEPOL, aerosol extinction, AOD, and lidar ratio from the HSRL methodology are not available in some cases, particularly when the aerosol loading was small. In these cases, the aerosol extinction at 355 and $532 \mathrm{~nm}$ is derived using the aerosol backscatter and an assumed lidar ratio of $40 \mathrm{sr}$ and reported at the backscatter resolution. In other cases where the HSRL method is available for extinction products, they are reported at $150 \mathrm{~m}$ vertical resolution and at temporal resolution of $60 \mathrm{~s}$ generally and $10 \mathrm{~s}$ within smoke plumes. Calibrated aerosol backscatter derived using the HSRL method is available in all cases. Problems with the ER-2 coolenol pump and a circuit breaker caused HSRL-2 data gaps on the 27 October flight and loss of HSRL-2 data on the 1 November flight.

\subsection{Ground observations}

Ground-based observations are valuable in that they can be used to validate or calibrate aircraft instrument measurements, or provide context for those observations. While not part of the ACEPOL field campaign, ground sites of two instrument networks served as targets for overflights. These networks (the Aerosol Robotic Network, or AERONET, and air quality monitors of the California Air Resources Board, or CARB) host their data in separate archives that are not under direct control of ACEPOL participants. A third effort, also ground based, involved deployment of radiometric and atmospheric measurement at Rosamond Dry Lake. The collection of these data was funded by ACEPOL, and they are archived at the locations in Table 3.

\subsubsection{Aerosol Robotic Network (AERONET) sites}

The Aerosol Robotic Network (AERONET; Holben et al., 1998 ) is a system of sun photometers used to produce global measurements of AOD, intensive properties (e.g., refractive index, size distribution), and precipitable water. This NASA product provides data recorded every 15 min utilizing many spectral bands, and the data are available at the AERONET archive (https://aeronet.gsfc.nasa.gov/, last access: 3 September 2020). During ACEPOL, the Modesto, Fresno-2, CalTech, and Bakersfield sites in California were operational 
Table 3. ACEPOL data availability. Archives for the primary ACEPOL instruments (ASDC, AirMSPI, and GroundMSPI) contain calibrated Level 1 data with direct physical observations, e.g., radiance, degree of linear polarization, and backscatter. Level 2 data are products of retrieval algorithms and include, for example, aerosol intensive and extensive parameters. These may or may not exist in the database(s) depending on the retrieval algorithm maturity. Last access for all URLs: 3 September 2020.

\begin{tabular}{ll}
\hline Archive & URL, DOI \\
\hline ASDC & $\begin{array}{l}\text { https://asdc.larc.nasa.gov/project/ACEPOL } \\
\text { https://doi.org/10.5067/SUBORBITAL/ACEPOL2017/DATA001 }\end{array}$ \\
\hline AirMSPI & $\begin{array}{l}\text { https://eosweb.larc.nasa.gov/project/airmspi/airmspi_table } \\
\text { https://doi.org/10.5067/AIRCRAFT/AIRMSPI/ACEPOL/RADIANCE/ELLIPSOID_V006 } \\
\text { https://doi.org/10.5067/AIRCRAFT/AIRMSPI/ACEPOL/RADIANCE/TERRAIN_V006 }\end{array}$ \\
\hline GroundMSPI & $\begin{array}{l}\text { https://eosweb.larc.nasa.gov/project/airmspi/airmspi_table } \\
\text { https://doi.org/10.5067/GROUND/GROUNDMSPI/ACEPOL/RADIANCE_v009 }\end{array}$ \\
\hline AERONET & https://aeronet.gsfc.nasa.gov/ \\
\hline CARB & https://www.arb.ca.gov/adam/index.html \\
\hline
\end{tabular}

and were routinely targeted. Additional AERONET sites that were targeted during the campaign are the USGS Flagstaff site in Arizona and the USC SeaPRISM site. The latter is part of a sub-network designated AERONET-Ocean Color (AERONET-OC). This network comprises enhanced instruments that have the ability to determine water-leaving radiance in addition to aerosol optical properties (Zibordi et al., 2009).

\subsubsection{California Air Resources Board (CARB) sites}

Air particulates are measured by the California Air Resources Board (CARB) throughout the state. A majority of CARB sites report $\mathrm{PM}_{2.5}$ (particulate matter with an aerodynamic diameter of less than $2.5 \mu \mathrm{m}$ ) and $\mathrm{PM}_{10}$ (particulate matter with a diameter of less than $10 \mu \mathrm{m}$ ), as determined by a variety of measurements, including particle counting and mass spectrometry. Gaseous criteria for air pollutants that are regulated in California and at the national level are also measured and reported to ensure compliance with U.S. Environmental Protection Agency (U.S. EPA) air quality standards and are stored at the CARB archive (https://www.arb.ca.gov/ adam/index.html, last access: 3 September 2020).

In addition to CARB total PM monitors, several speciated EPA PM monitors are located in California's San Joaquin Valley (SJV) including Modesto, Fresno, Visalia, and Bakersfield. The speciated PM monitors in Modesto, Fresno, and Bakersfield are collocated with AERONET instruments making these sites very useful for determining connections between near-surface PM loading and atmospheric aerosols. Modesto, Fresno, and Bakersfield sites were regularly targeted throughout the campaign.

\subsubsection{Rosamond Dry Lake ground instrumentation}

Vicarious calibration (VicCal) is the process of calibrating an on-orbit or aircraft sensor by observation of an Earth target which is characterized for its optical properties. A radiative transfer program is then used to propagate the surface measurements into a radiance incident on the flight sensor. Ground measurements made in support of ACEPOL vicarious calibration were performed on 25 October 2017, at Rosamond Dry Lake $\left(34.858704^{\circ} \mathrm{N}, 118.07638^{\circ} \mathrm{W}\right)$. This included measurements of surface reflectance and total column optical depth at the time of overflight, roughly 18:00 UTC. Data were processed at JPL and are hosted in the ACEPOL archive. These data were used by the AirMSPI team to derive a multiplier needed to adjust the laboratory-derived radiometric gain coefficient. For the Rosamond VicCal, the ratio of radiances using the laboratory calibration to the VicCalmeasured radiances was found to be low for the UV bands (0.85) but within $2 \%$ of unity for the remaining visible bands. The discrepancy in the UV lands is under investigation, but one error candidate is the low light level for these bands during the laboratory calibration.

The VicCal campaign at Rosamond included measurements of surface reflectance and total column optical depth at the time of overflight, roughly 18:00 UTC. Results of these measurements are shown in Figs. 8 and 9. AOD was measured by two Microtops and a Reagan sun photometer. The Microtops are handheld instruments, with spectral bands at $440,675,870,938$, and $1020 \mathrm{~nm}$. The Reagan sun photometer (Bruegge et al., 1992; Shaw et al., 1973), built at the University of Arizona, is an auto-tracking sun photometer, with channels at 370, 400, 440, 520, 620, 670, 780, 870, 940, and $1030 \mathrm{~nm}$. The instrument was calibrated via the Langley method by taking early morning data the day before the ER-2 overflight. A discrepancy is noted in the Microtops data, perhaps due to an error in its surface pressure. 


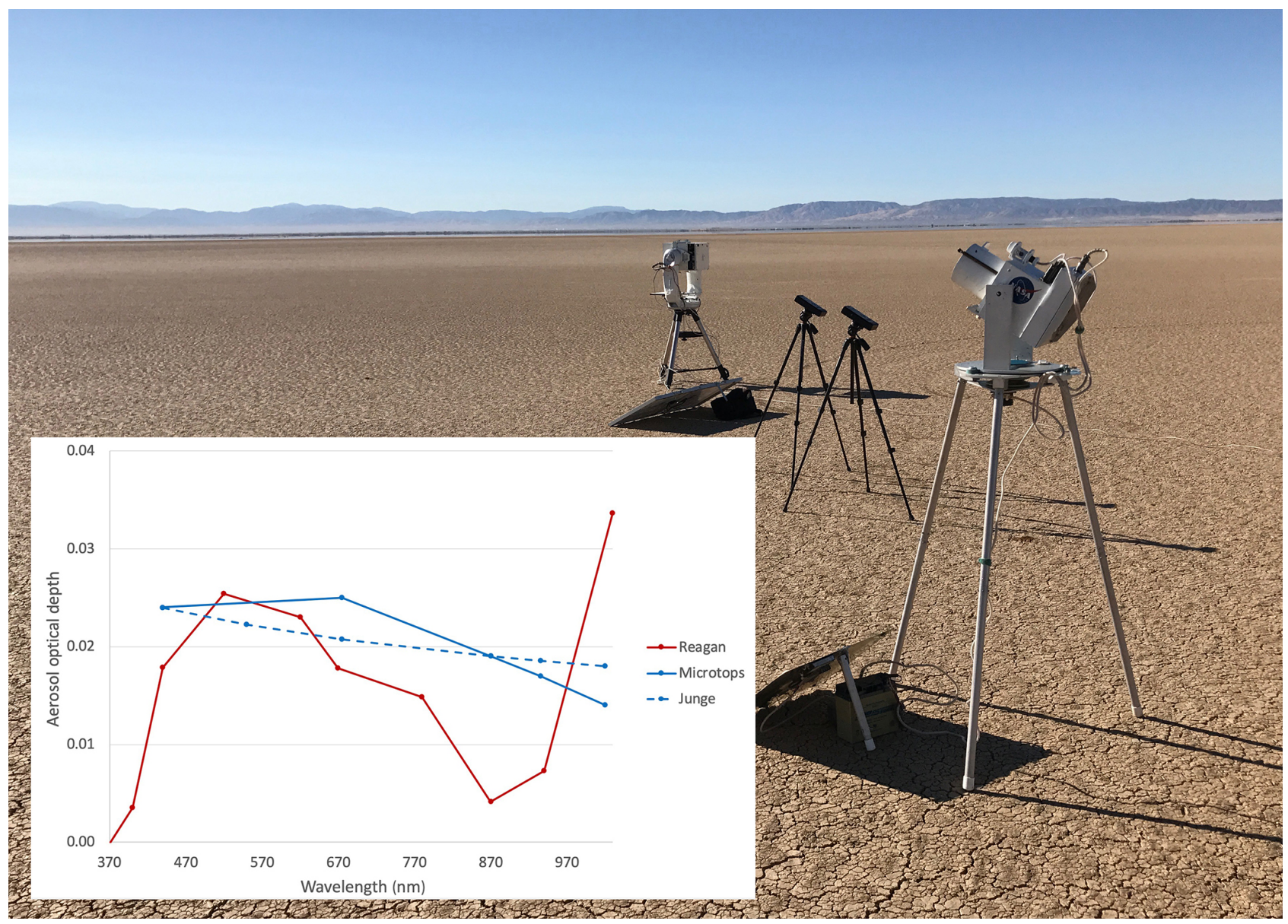

Figure 8. GroundMSPI, two Microtops sun photometers, and a University of Arizona Reagan sun photometer deployed on 25 October 2017 at Rosamond Dry Lake in California. (Inset) AOD as measured by the Microtops and Reagan sun photometers, plus a Junge model fit to the Microtops data.

As the Reagan instrument was calibrated in situ, its output was considered higher in accuracy and used in the AirMSPI VicCal. Also shown in Fig. 8 is the Junge model fit to the Microtops data, which assumes a linear relationship on a log-log scale of aerosol optical depth versus wavelength. Surface reflectance was measured by the Analytical Spectral Devices (ASD) FieldSpec 4 instrument. This measures from 350 to $2500 \mathrm{~nm}$ with $1 \mathrm{~nm}$ samples with resolution at $3 \mathrm{~nm}$ (VIS, NIR) and $10 \mathrm{~nm}$ (SWIR). Data were taken over a $500 \mathrm{~m} \times 500 \mathrm{~m}$ area, along with spectra of a Spectralon $100 \%$ diffuse reflectance standard. To report radiances, the Spectralon data are interpolated at the target sample times and corrected for Spectralon bidirectional reflectance. The ratio of the target to interpolated Spectralon data provides a persample reflectance, which is then averaged to provide a site average.

Operating alongside the vicarious calibration instrumentation was the Ground-based Multiangle SpectroPolarimetric Imager (GroundMSPI) instrument (see Fig. 8). The specifications of the GroundMSPI camera are similar to AirMSPI (see
Sect. 3.1.2), including the eight spectral bands within 355$935 \mathrm{~nm}$, with 470,660 , and $865 \mathrm{~nm}$ being polarimetric. The camera is mounted $\sim 1 \mathrm{~m}$ from the ground on a motorized altazimuth tripod. GroundMSPI performed continuous elevation scans at different azimuths to image the surface as well as the clear sky. The surface observations provide a direct measurement of the polarized bidirectional reflectance distribution function ( $\mathrm{p}$-BRDF), including potential spectral variance, whereas the sky radiance and polarization data serve as input for aerosol retrievals, either independently or combined with the airborne sensors. On 7 November 2017, GroundMSPI performed sky scans at the Fresno AERONET station during ER2 and Cloud-Aerosol Lidar and Infrared Pathfinder Satellite Observations (CALIPSO) overpasses. GroundMSPI L1B2 rectified and co-registered radiometric and polarimetric data, and quick looks are available as noted in the Data availability section. 


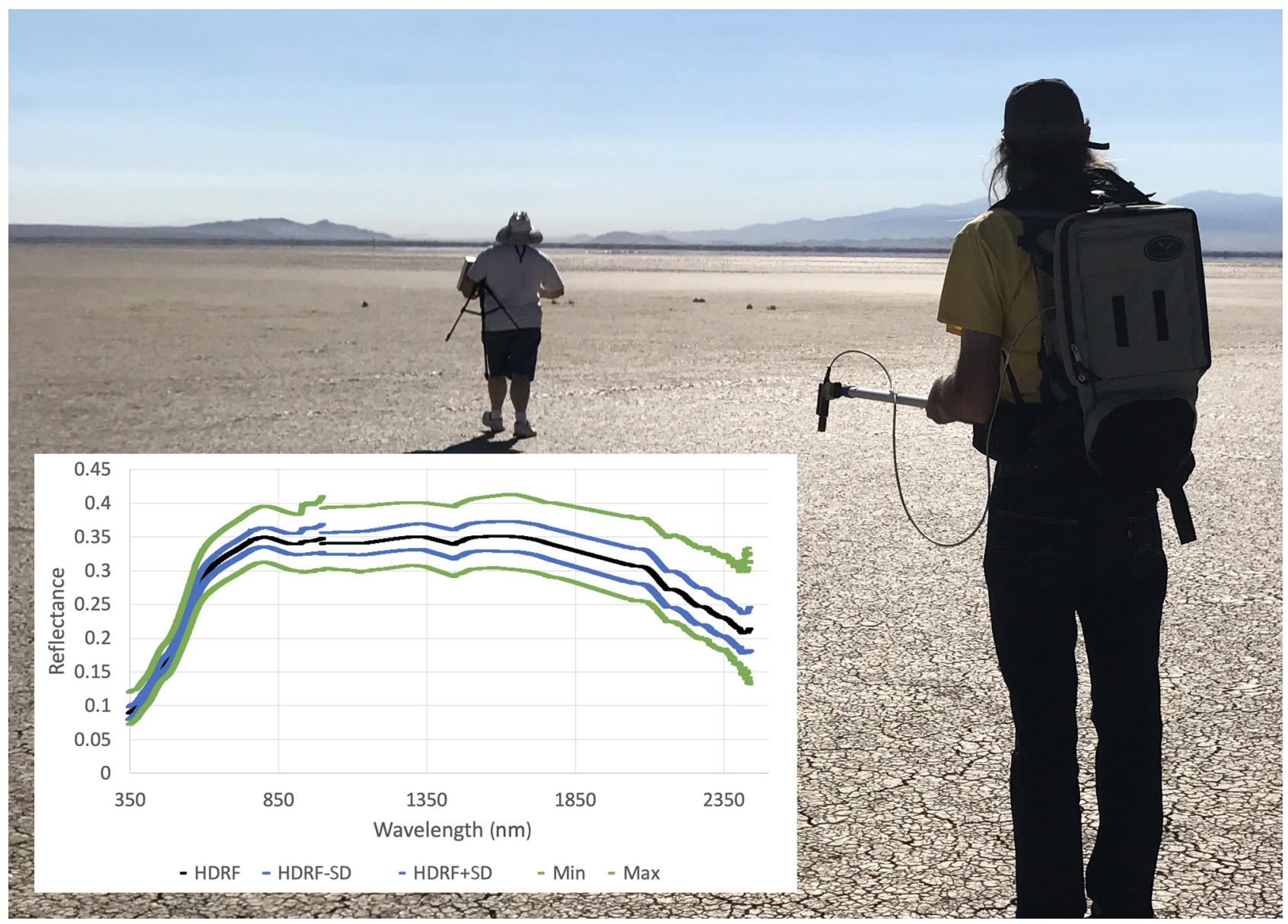

Figure 9. Surface characterization on 25 October 2017 at Rosamond Dry Lake in California using a Spectralon reflectance standard and ASD FieldSpec Pro. (Inset) Mean and standard deviation of surface reflectance (black, blue lines) with maxima and minima spectra (green). Reflectances are presented in terms of the hemispherical-directional reflectance factor (HDRF), Schaepman-Strub et al. (2006).

\section{Deployment}

\subsection{Flight planning}

Daily flight planning was informed by weather and aerosol forecasts from NASA's Global Modeling and Assimilation Office (GMAO, https://gmao.gsfc.nasa.gov, last access: 3 September 2020) and the European Centre for Medium-Range Weather Forecasts (ECMWF, http://ecmwf. int, last access: 3 September 2020), satellite imagery from several geostationary and polar orbiting satellites (e.g., GOES-16, MODIS, VIIRS), and fire weather outlooks from NOAA's Storm Prediction Center (https://www.spc.noaa. gov/products/fire_wx, last access: 3 September 2020). Flight plans were drafted based on forecast information and adjusted in real time to account for the rapid changes in fire and weather conditions. See Table 4 for detailed information about each flight. This table lists relevant information about each flight, including observed targets, instrument status, and coordinated observations with satellite, ground, or other aircraft observations. Local time at AFRC is UTC - 08:00.
Scenes of particular interest are highlighted in bold. The "Moving Lines" flight planning tool (LeBlanc, 2018) was used to prepare for all flights, along with weather forecasting support of the NASA Global Modeling and Assimilation Office (GMAO).

\subsection{Aircraft operations}

All airborne sensors were deployed together on the NASA Lockheed Earth Resources (ER-2) aircraft, based at the NASA AFRC in Palmdale, California. The ER-2 is a highaltitude aircraft, capable of flying up to roughly $21 \mathrm{~km}$ $(68000 \mathrm{ft})$, above most of the Earth's atmosphere. Flights were contained within the continental United States and offshore, primarily in California, Nevada, and Arizona. The aircraft altitude, range, and the variety of conditions within that range made the ER-2 deployment from AFRC an excellent orbital analogue platform.

Figure 10 is a graphical illustration of ACEPOL flight tracks with more information in Table 4. Generally, atmo- 
Table 4. Daily description of ACEPOL flights. Nine flights, with a total of 40.1 flight hours, were carried out between 19 October 2017 and 9 November 2017 for ACEPOL. Scenes of particular interest are highlighted in bold.

\begin{tabular}{|c|c|c|c|c|c|c|}
\hline Flight date & Takeoff (UTC) & Duration (h) & Targets achieved & Instrument status & $\begin{array}{l}\text { Coordinated } \\
\text { observations }\end{array}$ & Notes \\
\hline 19 Oct & $16: 09$ & 2 & $\begin{array}{l}\text { 1e, CATS: } 17: 32 \\
\text { 10: } 18: 00\end{array}$ & $\begin{array}{l}\text { All instruments func- } \\
\text { tioning }\end{array}$ & $\begin{array}{l}\text { CATS, } \\
\text { AERONET }\end{array}$ & $\begin{array}{l}\text { Test flight recalled } \\
\text { early due to high winds } \\
\text { at landing site. Be- } \\
\text { cause of recall, missed } \\
\text { potential coordination } \\
\text { with CASPER in situ } \\
\text { sampling in Central } \\
\text { Valley. }\end{array}$ \\
\hline $23 \mathrm{Oct}$ & $17: 01$ & 5.7 & $\begin{array}{l}\text { 1a, late in flight } \\
\text { 1d, San Francisco Bay: } \\
\text { 19:27 } \\
\text { Catalina Island: } 21: 07 \\
\text { 2a, Bakersfield: 17:50, } \\
\text { 18:40 } \\
\text { 2b, Modesto: 19:20 } \\
\text { USC_SeaPRISM: } \\
\text { 21:07 } \\
\text { 3a, Terra: } 18: 40 \\
\text { 10: } 19: 54-20: 26\end{array}$ & $\begin{array}{l}\text { All instruments func- } \\
\text { tioning }\end{array}$ & $\begin{array}{l}\text { Terra (MODIS } \\
\& \text { MISR) } \\
\text { AERONET, } \\
\text { AERONET-OC }\end{array}$ & $\begin{array}{lrr}\text { Severe } & \text { clear } \text { (few } \\
\text { clouds, low aerosol } \\
\text { load) flight with } \\
\text { satellite r coordina- } \\
\text { tion. Overflight of } \\
\text { ocean AERONET } \\
\text { USC_SeaPRISM site } \\
\text { has ideal geometry for } \\
\text { polarimeters, subject } \\
\text { of comparison studies. }\end{array}$ \\
\hline $25 \mathrm{Oct}$ & $16: 30$ & 5.9 & $\begin{array}{l}\text { 1a, near coast: } 20: 49 \\
\text { 1b, five legs over } \\
\text { Rosamond Dry lake: } \\
\text { 17:18, 17:50, 18:21, } \\
\text { 18:47, 19:24 } \\
\text { 1d, near coast: 20:49, } \\
\text { Salton Sea: } 21: 17 \\
\text { 2a, CalTech: 18:25, } \\
\text { Fresno: } 20: 15, \\
\text { 2b, } \\
\text { USC_SeaPrism:18:30, } \\
\text { Bakersfield: } 19: 45\end{array}$ & $\begin{array}{l}\text { All instruments func- } \\
\text { tioning }\end{array}$ & $\begin{array}{l}\text { GroundMSPI } \\
\text { at Rosamond } \\
\text { Dry Lake } \\
\left(34.85636^{\circ} \mathrm{N},\right. \\
\left.118.07649^{\circ} \mathrm{W}\right), \\
\text { AERONET, } \\
\text { AERONET-OC }\end{array}$ & $\begin{array}{l}\text { Severe clear, primary } \\
\text { focus was overflights } \\
\text { of Rosamond Dry } \\
\text { Lake while a ground } \\
\text { team characterized } \\
\text { surface reflectance. }\end{array}$ \\
\hline $26 \mathrm{Oct}$ & $18: 00$ & 4.5 & $\begin{array}{l}\text { 1d, S. California coast: } \\
\text { 19:40, Salton Sea: } \\
\text { 19:53 } \\
\text { 1e, CALIPSO under- } \\
\text { flight: } 20: 50 \\
\text { 2a, Fresno: 18:48 } \\
\text { 2b, Bakersfield: 19:11 }\end{array}$ & $\begin{array}{l}\text { All instruments func- } \\
\text { tioning }\end{array}$ & $\begin{array}{l}\text { CALIPSO, } \\
\text { AERONET }\end{array}$ & $\begin{array}{l}\text { Central } \\
\text { AERONET Valley } \\
\text { flights, followed by } \\
\text { CALIPSO track co- } \\
\text { ordination. } \\
\text { free. }\end{array}$ \\
\hline 27 Oct & $17: 00$ & 3.2 & $\begin{array}{l}\text { 3a, Terra: } 18: 21 \\
\text { 4b, smoke from fires: } \\
\text { 18:00, 18:32, 18:55 }\end{array}$ & $\begin{array}{l}\text { All instruments func- } \\
\text { tioning, some HSRL } \\
\text { gaps (ER-2 cooling } \\
\text { problem) }\end{array}$ & $\begin{array}{l}\text { AERONET } \\
\text { Terra (MODIS } \\
\& \text { MISR) }\end{array}$ & $\begin{array}{l}\text { Flight targeting pre- } \\
\text { scribed burns in } \\
\text { Arizona. Cloud free. }\end{array}$ \\
\hline $1 \mathrm{Nov}$ & $16: 35$ & 5 & $\begin{array}{l}\text { 1c, S. California coast: } \\
\text { 17:30 } \\
\text { 2a, Bakersfield: 17:00 } \\
\text { 2b, Flagstaff: } 19: 20 \\
\text { 3a, Terra: 18:39 } \\
\text { 4b, smoke from fires: } \\
\text { 19:12 } \\
\text { 9, Los Angeles basin: } \\
\text { 17:45 }\end{array}$ & $\begin{array}{l}\text { No HSRL (ER-2 cool- } \\
\text { ing problem), only } \\
\text { one AirMSPI target, } \\
\text { Reduced AirHARP } \\
\text { observations }\end{array}$ & $\begin{array}{l}\text { AERONET } \\
\text { Terra (MODIS } \\
\& \text { MISR) }\end{array}$ & $\begin{array}{l}\text { Marine stratocumulus } \\
\text { clouds off S. California, } \\
\text { then smoke in Arizona. }\end{array}$ \\
\hline 3 Nov & $18: 58$ & 2.9 & $\begin{array}{l}\text { 9: } 20: 00,20: 42 \\
\text { 10: } 21: 10\end{array}$ & $\begin{array}{l}\text { All instruments func- } \\
\text { tioning }\end{array}$ & & $\begin{array}{l}\text { Short flight to test } \\
\text { aircraft/instrument } \\
\text { repairs. California } \\
\text { Central Valley with } \\
\text { multilayered clouds. }\end{array}$ \\
\hline
\end{tabular}


Table 4. Continued.

\begin{tabular}{|c|c|c|c|c|c|c|}
\hline Flight date & Takeoff (UTC) & Duration (h) & Targets achieved & Instrument status & $\begin{array}{l}\text { Coordinated } \\
\text { observations }\end{array}$ & Notes \\
\hline $7 \mathrm{Nov}$ & $17: 19$ & 5.3 & $\begin{array}{l}\text { 1a: 20:31 } \\
\text { 1d, Monterey Bay: } \\
\text { 20:16 } \\
\text { 1e, CALIPSO un- } \\
\text { derflight, California } \\
\text { Central Valley: } 21: 18 \\
\text { 2a, Bakersfield: 17:55, } \\
\text { 19:06, 21:57, Fresno: } \\
\text { 19:40, Modesto: 20:06 } \\
\text { 2b, CalTech: } 18: 10 \\
\text { 10: } 18: 21,20: 40\end{array}$ & $\begin{array}{l}\text { AirHARP lost heater, } \\
\text { no data for end of flight }\end{array}$ & $\begin{array}{l}\text { CALIPSO, } \\
\text { AERONET }\end{array}$ & $\begin{array}{l}\text { Targeting AERONET } \\
\text { sites and CALIPSO } \\
\text { track, plus clear seg- } \\
\text { ment over the ocean. }\end{array}$ \\
\hline $9 \mathrm{Nov}$ & $17: 16$ & 5.6 & 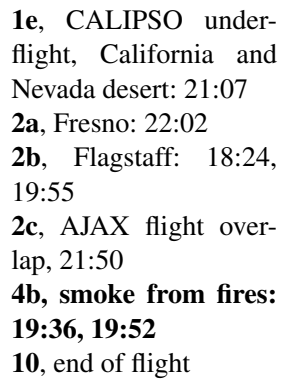 & $\begin{array}{l}\text { All instruments func- } \\
\text { tioning }\end{array}$ & $\begin{array}{l}\text { CALIPSO, } \\
\text { AERONET, } \\
\text { AJAX }\end{array}$ & $\begin{array}{l}\text { Return to Arizona for } \\
\text { smoke near the Grand } \\
\text { Canyon, successfully } \\
\text { observed high aerosol } \\
\text { loads. CALIPSO under } \\
\text { flight, coincident mea- } \\
\text { surement with AJAX } \\
\text { flight. }\end{array}$ \\
\hline
\end{tabular}

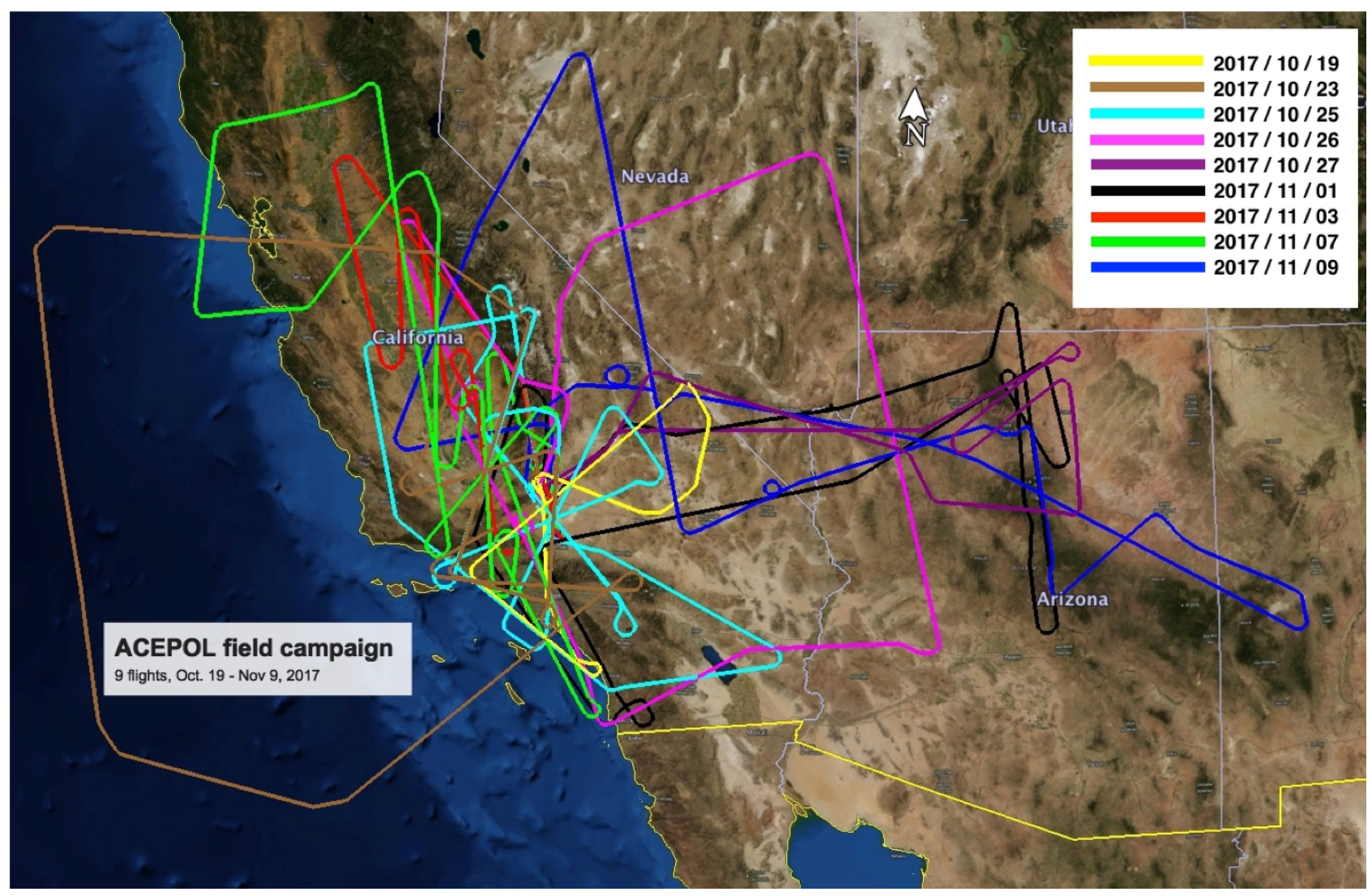

Figure 10. Flight tracks for the ACEPOL field campaign. Nine flights were conducted from 19 October to 9 November 2017 over California, Nevada, Arizona, New Mexico, and the coastal Pacific Ocean from the Armstrong Flight Research Center in Palmdale, California. Image mapped using Google Earth, (c) 2018 Google. 
spheric conditions during ACEPOL were clear, with very low aerosol loads, and few clouds. The range of the ER-2 helped compensate for these somewhat unusual low aerosol conditions, providing for cloud observations in northern California or offshore, and deployments east over Arizona to overfly prescribed forest fire burns near the Grand Canyon in Arizona.

One of the priorities of ACEPOL was coordinated overflights of ground sites to validate retrievals by the remote sensing instruments. AERONET sun photometers were overflown on all days except the test flights on 19 October and 3 November. Often, these overflights were planned so that the aircraft heading was close to the solar principal plane (SPP), which maximizes the scattering angle range of MAP observations in order to increase the measured information. The AERONET-OC site "USC_SEAPRISM", located on an oil platform off Newport Beach, California, was of particular interest because of the capability for concurrent ocean and atmosphere measurements. This site was targeted on multiple days. Since CARB particulate matter monitoring sites are often co-located with AERONET sites (especially in the California Central Valley), these were frequently monitored as well.

On the last ACEPOL flight (9 November), there was a serendipitous overflight of a (lower-altitude) flight by an Alpha Jet stationed at the NASA Ames Research Center (ARC) as part of the Alpha Jet Atmospheric Experiment (AJAX) flight series (Hamill et al., 2016). The Alpha Jet was instrumented with a wing pod sampling gas concentrations of $\mathrm{CO}_{2}$, $\mathrm{CH}_{4}, \mathrm{H}_{2} \mathrm{O}, \mathrm{O}_{3}$, and $\mathrm{HCHO}$, plus 3D wind speeds, temperature, and pressure, and preceded the ER-2 by about $1 \mathrm{~h}$ in an area of the eastern Sierra Nevada Mountains.

\subsection{Example scene}

ACEPOL brings together four multi-angle polarimeters and two lidars which have disparate observation characteristics. An example of this is shown in Fig. 11. This scene, an overflight of prescribed burns near the Grand Canyon on 27 October 2017, was observed by all instruments, although CPL and RSP data are omitted from this figure for clarity. Aerosol backscatter in the lidar data (HSRL shown, CPL omitted) shows smoke in the process of either being lofted by surface topography or trapped by that topography. Large-scale AirHARP data indicate the horizontal extent of the smoke plume, while high-spatial-resolution AirMSPI data demonstrate fine-scale spatial variability. Continuous sampling polarimeters (SPEX airborne, shown, RSP, omitted) capture the atmospheric state for the entire flight. All instruments can be used to further derive the aerosol optical properties to varying degrees of success, depending on observation information content and retrieval algorithm design. Because of the overlapping nature of such observations, these scenes provide a test of retrieval capability (e.g., Fu et al., 2020; Gao et al., 2020; McBride et al., 2020; Puthukkudy et al., 2020) .
They can also be used to investigate algorithms that incorporate data from multiple instruments.

\section{Value for future missions}

\subsection{Aerosol, Cloud, Convection and Precipitation (ACCP) mission study}

ACEPOL was designed to evaluate instrument designs under consideration for the ACE mission study, which had scientific goals that are still relevant today. As evidence, the 2017 Decadal Survey of the National Academies of Sciences, Engineering, and Medicine (National Academies of Sciences, Engineering, and Medicine, 2018) identified targeted observables ("aerosols" and "clouds, convection, and precipitation"). In response, NASA is now conducting the Aerosol, Cloud, Convection and Precipitation (ACCP) pre-formulation study (https://science.nasa.gov/ earth-science/decadal-accp, last access: 3 September 2020). Spaceborne versions of the airborne lidar and polarimeters that participated in ACEPOL are under consideration for ACCP. Hence, ACEPOL data play an important role in ACCP activities.

\subsection{Hyper Angular Rainbow Polarimeter (HARP) CubeSat}

AirHARP provides an excellent proxy dataset for the development of HARP CubeSat algorithms. The two instruments are nearly identical, although AirHARP experienced temperature, vibrational, and humidified conditions on aircraft that are not present in space. Like AirHARP, the HARP CubeSat does not have an onboard calibrator, so many of the correction techniques used on the AirHARP data will carry over to the CubeSat data. However, by pointing the spacecraft, the HARP CubeSat sensor is capable of lunar, limb, and deep space views, as well as coverage over a larger variety of surfaces, which may improve post-processing and vicarious data calibrations.

The synergy between AirHARP and other ACEPOL instruments provides excellent opportunities to study design and sampling, with relevance to HARP CubeSat. Because of altitude and bandwidth limitations, the instruments have different spatial resolutions. For AirHARP, ground pixel is much smaller $(55 \mathrm{~m})$ than it will be from HARP CubeSat (about $4 \mathrm{~km}$ at nadir). AirHARP retrievals can be used to study small-scale variabilities in a cloud field (McBride et al., 2020) and smoke plume (Puthukkudy et al., 2020). These features will be much less resolved in HARP CubeSat data, which is better suited for intercomparisons with MODIS and other satellite instruments. As a technology demonstration, the amount of data collected by HARP CubeSat is severely constrained by spacecraft storage and downlink capabilities, allowing for a single scene per day. This limitation is not 


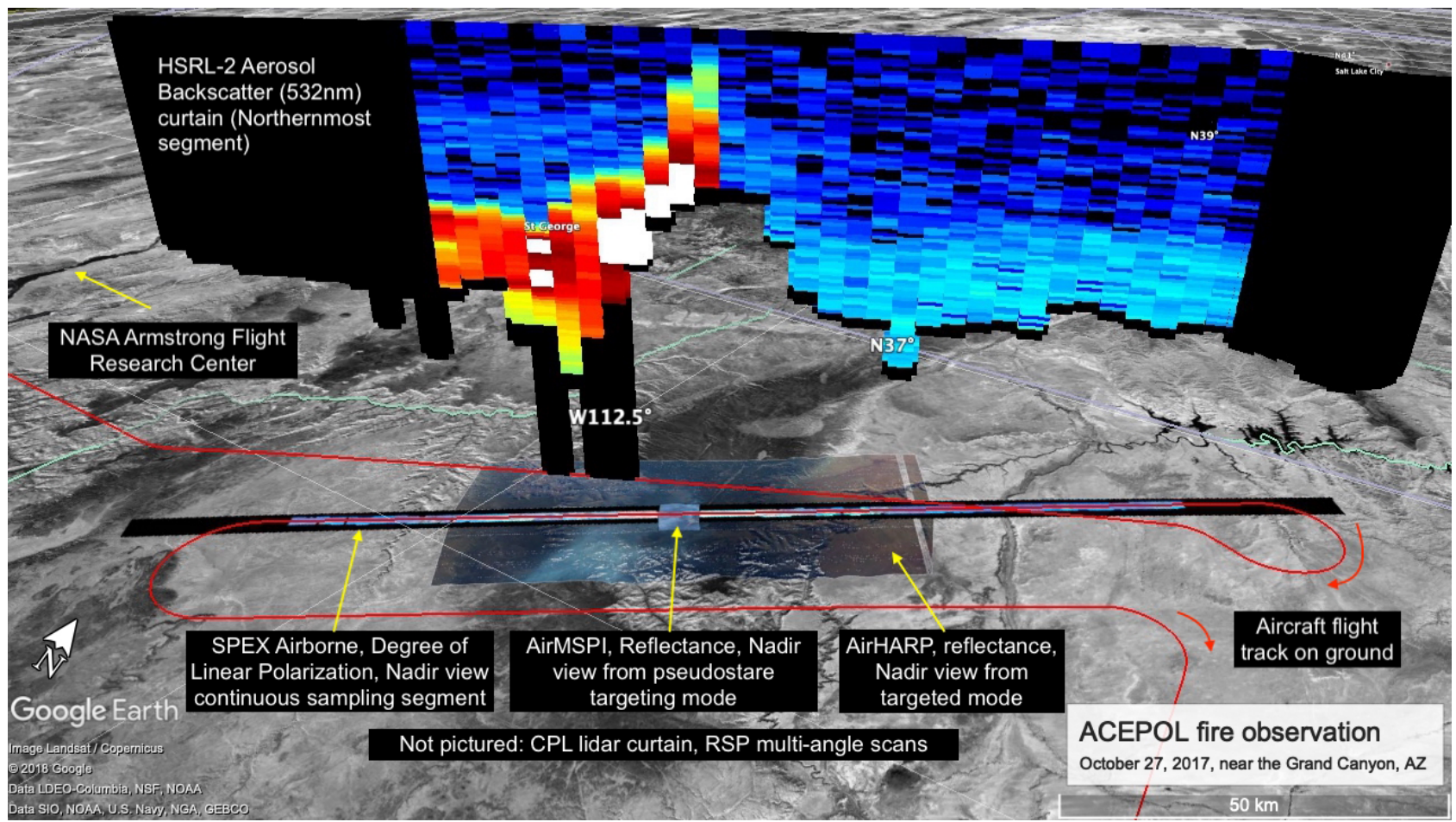

Figure 11. Example of variable instrument observation characteristics for a scene on 27 October 2017, of biomass burning smoke from prescribed burns near the Grand Canyon. Image mapped using Google Earth, () 2018 Google.

present in future versions of the HARP payload, such as HARP2 on PACE.

\subsection{Multi-Angle Imager for Aerosols (MAIA)}

NASA selected the Multi-Angle Imager for Aerosols (MAIA) investigation (Diner et al., 2018) as part of the third Earth Venture Instrument (EVI-3) solicitation. MAIA's primary objective is to assess the impacts of different types of airborne particulate matter (PM) on human health, where "type" refers to the proportions of aerosols having different sizes, shapes, compositions, and speciated particulate matter counts. The satellite instrument contains a push-broom multispectral and polarimetric camera mounted on a two-axis gimbal. Along-track pointing (up to $\pm 60^{\circ}$ ) enables multiangle observations over a discrete set of globally distributed target areas, while cross-track pointing provides the camera with a wide cross-track field of regard $\left( \pm 45^{\circ}\right)$, permitting frequent revisits of the designated targets. MAIA makes use of the same dual-PEM polarimetric imaging approach as AirMSPI and extends the spectral range into the shortwave infrared (SWIR). The camera includes 14 spectral bands in the ultraviolet (UV), visible-near-infrared (VNIR), and SWIR, of which three are polarimetric $(442,645$, and $1040 \mathrm{~nm})$. Channels near the $\mathrm{O}_{2}$ A-band $(749,762.5 \mathrm{~nm})$ are included to explore sensitivity to aerosol layer (and cloud) height. Launch into a $740 \mathrm{~km}$ sun-synchronous, ascending node or- bit with 10:30 Equator-crossing time is planned for mid-2022 aboard the General Atomics Orbital Test Bed-2 spacecraft. MAIA measurements will be used to retrieve total AOD and column effective aerosol optical and microphysical properties at $1 \mathrm{~km}$ spatial resolution, using an optimal estimation algorithm (Xu et al., 2017). A geostatistical regression modeling framework will be used to transform column aerosol optical and microphysical properties to speciated, near-surface PM concentrations (Kalashnikova et al., 2018). During ACEPOL, AirMSPI collected imagery over speciated PM and AERONET sites, while HSRL-2 obtained independent data regarding aerosol types and their vertical distributions, making the campaign a valuable source of information for testing and validation of MAIA algorithms.

\subsection{Plankton, Aerosol, Cloud, ocean Ecosystem (PACE) mission}

The NASA PACE mission, due to be launched in late 2022, will contain three instruments. The primary instrument is the Ocean Color Imager (OCI), a UV-VIS spectrometer designed for Ocean Color remote sensing applications. OCI also has channels in the SWIR and will also perform retrievals of aerosol, cloud, and land surface geophysical properties. The PACE payload will also contain two, contributed, MAPs. Airborne prototypes of these instruments, with similar characteristics, were flown as part of ACEPOL. AirHARP 
is the airborne prototype of PACE/HARP2, while SPEX airborne is the prototype of PACE/SPEXone (Werdell et al., 2019; Hasekamp et al., 2019). For these reasons, ACEPOL data provide a valuable resource for the development of remote sensing strategies for PACE, by acting as a proxy for the MAPs on PACE. The spectrometer characteristics of SPEX airborne can also serve as a proxy for the OCI UV-VIS spectrometer, while the SWIR channels on RSP (with some exceptions) can stand in for those on OCI. Furthermore, the characteristics of other MAPs deployed during ACEPOL can be used to understand the impact of PACE design decisions. Additionally, coincident observation by other instruments, namely the CPL and HSRL-2 lidars, can be used to validate assessed retrievals. Studies of these observations in the context of PACE are active and underway (e.g., Smit et al., 2019; Fu et al., 2020).

\subsection{Upcoming SPEX airborne deployments}

As part of the EU Horizon 2020 project SCARBO (Space Carbon Observatory) it is planned that SPEX airborne will participate in an airborne campaign in September 2020 (depending on the COVID-19 situation), flying together with two instruments that measure $\mathrm{CO}_{2}$. The goal is to use aerosol measurements from SPEX airborne to improve $\mathrm{CO}_{2}$ retrievals from two instruments dedicated to $\mathrm{CO}_{2}$ retrieval: the MAMAP (Methane Airborne Mapper) spectrometer (Krings et al., 2011) and the NanoCarb interferometer (Ferrec et al., 2019) The flights will depart from Toulouse and will cover (parts of) France, Spain, Italy, and Germany. The aircraft for the SCARBO campaign will be a Falcon that will fly between 2 and $10 \mathrm{~km}$ altitude. For upcoming deployments, the dataprocessing chain (from level 0 to level 2) will make full use of the algorithm processor performed for ACEPOL (Smit et al., 2019; Fu et al., 2020).

\section{Data availability}

The primary repository for ACEPOL data is the NASA Atmospheric Science Data Center (ASDC), at the Langley Research Center. AirMSPI and GroundMSPI data are stored separately at the ASDC, while AERONET data are located at their own archive. Air quality from California are stored at the CARB website. AJAX data are available by request to the PI, Laura Iraci, at NASA ARC. The DOI for the primary database is https://doi.org/10.5067/SUBORBITAL/ACEPOL2017/

DATA001 (ACEPOL Science Team, 2017), while for AirMSPI it is https://doi.org/10.5067/AIRCRAFT/ AIRMSPI/ACEPOL/RADIANCE/ELLIPSOID_V006 and https://doi.org/10.5067/AIRCRAFT/AIRMSPI/ACEPOL/ RADIANCE/TERRAIN_V006 (ACEPOL AirMSPI Science Team, 2017a, b). GroundMSPI data are at https://doi.org/10.5067/GROUND/GROUNDMSPI/ACEPOL/
RADIANCE_v009 (GroundMSPI Science Team, 2017). Table 3 lists further details of these archives.

\section{Conclusions}

The ACEPOL field campaign explored techniques for remote sensing of aerosol and cloud optical properties with a variety of MAP and lidar designs. Roughly four categories of observations were targeted: those that aid in radiometric property calibration or validation, those supporting geolocation tests, those for validating the retrieval of derived geophysical parameters, and "targets of opportunity" representing difficult or rarely observed scenes to use in algorithm development. The field campaign was largely a success: all instruments were operational with limited outages for technical or engineering problems, and data have been processed and archived. Conditions were sufficient to achieve most of the primary objectives, although unusually low aerosol loads compelled the research aircraft to target forest fires further afield.

These co-located observations, gathered in a diversity of conditions, are a valuable resource for algorithm development, instrument design, and other studies, and they are archived in publicly available databases. Furthermore, the coordination and teamwork demonstrated during this successful field campaign can serve as a model for future campaigns, especially those that have multiple objectives, instrument teams, and funding institutions. 
Appendix A: Abbreviations and units

\begin{tabular}{|c|c|}
\hline ABI & Advanced Baseline Imager \\
\hline $\mathrm{ACCP}$ & Aerosol, Cloud, Convection and Precipitation \\
\hline ACEPOL & Aerosol Characterization from Polarimeter and Lidar \\
\hline AERONET & Aerosol Robotic Network \\
\hline AERONET-OC & Aerosol Robotic Network - Ocean Color \\
\hline AFRC NASA & Armstrong Flight Research Center \\
\hline AirHARP & Airborne Hyper Angular Rainbow Polarimeter \\
\hline AirMSPI & Airborne Multiangle SpectroPolarimetric Imager \\
\hline AJAX & Alpha Jet Atmospheric Experiment \\
\hline AOD & Aerosol optical depth \\
\hline ARC & NASA Ames Research Center \\
\hline ASD-AC & Airborne Science Data for Atmospheric Composition \\
\hline ASDC & Atmospheric Science Data Center (at NASA Langley Research Center) \\
\hline BPDF & Bidirectional polarization distribution function \\
\hline BRDF & Bidirectional reflectance distribution function \\
\hline CALIOP & Cloud-Aerosol Lidar with Orthogonal Polarization \\
\hline CALIPSO & Cloud-Aerosol Lidar and Infrared Pathfinder Satellite Observations \\
\hline CARB & California Air Resources Board \\
\hline CASPER & Coupled Air Sea Processes and EM Ducting Research \\
\hline CATS & Cloud-Aerosol Transport System \\
\hline CPL & Cloud Physics Lidar \\
\hline DISCOVER-AQ & $\begin{array}{l}\text { Deriving Information on Surface Conditions from COlumn and VERtically Resolved Observations } \\
\text { Relevant to Air Quality }\end{array}$ \\
\hline DOE & Department of Energy \\
\hline DoLP & Degree of Linear Polarization (unitless) \\
\hline ECMWF & European Centre for Medium-Range Weather Forecasts \\
\hline EPA & U.S. Environmental Protection Agency \\
\hline ER-2 & Lockheed Earth Resources 2 (aircraft) \\
\hline EVI & Earth Venture Instrument \\
\hline GroundMSPI & Ground-based Multiangle SpectroPolarimetric Imager \\
\hline GMAO & Global Modeling and Assimilation Office \\
\hline GOES-16 & Geostationary Operational Environmental Satellite - 16 \\
\hline GRASP & Generalized Retrieval for Aerosol and Surface Properties \\
\hline HARP2 & Hyper Angular Rainbow Polarimeter 2 (contribution to PACE mission) \\
\hline HDRF & Hemispherical-directional reflectance factor \\
\hline HIPP & Hyper-Angular Image Processing Pipeline \\
\hline HSRL-2 & High Spectral Resolution Lidar 2 \\
\hline $\mathrm{LaRC}$ & NASA Langley Research Center \\
\hline LMOS & Lake Michigan Ozone Study \\
\hline MAIA & Multi-angle Imager for Aerosols \\
\hline MAMAP & Methane Airborne Mapper \\
\hline MAP & Multi-angle polarimeter \\
\hline MAPP & Microphysical Aerosol Properties from Polarimetry (RSP algorithm) \\
\hline MISR & Multi-angle Imaging SpectroRadiometer \\
\hline MODIS & Moderate Resolution Imaging Spectroradiometer \\
\hline NASA & National Aeronautics and Space Administration \\
\hline NIR & Near infrared \\
\hline NIST & National Institute of Standards and Technology \\
\hline NSO & Netherlands Space Office \\
\hline NWO & $\begin{array}{l}\text { Nederlandse Organisatie voor Wetenschappelijk Onderzoek (Netherlands Organization for } \\
\text { Research) }\end{array}$ \\
\hline
\end{tabular}


ORACLES ObseRvations of Aerosols above CLouds and their intEractionS

P-3 Lockheed P-3 Orion (aircraft)

PACE Plankton, Aerosol, Cloud, ocean Ecosystem

PACS Passive Aerosol and Cloud Suite

PM Particulate matter

PODEX Polarimeter Definition Experiment

RSP Research Scanning Polarimeter

SCARBO Space Carbon Observatory

SeaBASS SeaWiFS Bio-Optical Archive and Storage System

SeaWiFS Sea-viewing Wide Field-of-view Sensor

SJV San Joaquin Valley

SPEX Airborne Spectrometer for Planetary Exploration

SPEXone Spectrometer for Planetary Exploration (contribution to PACE mission)

SPP Solar principal plane

sr Steradian

SRON Netherlands Institute for Space Research

SWIR Shortwave infrared

TCAP Two-Column Aerosol Project

ViCal Vicarious calibration

VIIRS Visible Infrared Imaging Radiometer Suite

VIS Visible (wavelengths) 
Author contributions. The ACEPOL field campaign is the product of a large team, many of whom are co-authors of this paper. KK led the creation of the manuscript. HM, AdS, and FCS conceived and supported the ACEPOL field campaign from NASA HQ. OH coordinated support of ACEPOL at NWO/NSO. RF and KK performed flight planning and coordinated the campaign in the field. AdS and KLDF provided meteorological support for field operations. KN led ground and aircraft support at AFRC. JVM is the PI for AirHARP, DJD is the PI for AirMSPI, BC is the PI for RSP, OH is the PI for SPEX airborne, MM is the PI for CPL, and JH is the PI for HSRL-2. CB lead the ground characterization at Rosamond Dry Lake. GC coordinates the data archive. All authors provided material for the manuscript and overall review.

Competing interests. The authors declare that they have no conflict of interest.

Acknowledgements. The ACEPOL field campaign would not have been possible without the professionalism and energy of the ER-2 pilots and ground crew and the overall support at the NASA Armstrong Flight Research Center.

Research at the Jet Propulsion Laboratory, California Institute of Technology was carried out under a contract with the National Aeronautics and Space Administration (80NM0018D0004).

We thank the United States Forest Service, in particular Jason Clawson and David Hercher, for providing information about planned prescribed burns in the Kaibab National Forest.

The principal investigator for the USC_SEAPRISM AERONETOC site is Curtiss O. Davis of Oregon State University. The site manager is Matthew Ragan of the University of Southern California.

Figure 11 was visualized using Google Earth.

Financial support. This research has been supported by the National Aeronautics and Space Administration (ACE mission study and CALIPSO mission), the Netherlands Institute for Space Research (SPEX instrument development), and the Netherlands Space Office (SPEX instrument development).

Review statement. This paper was edited by Alexander Kokhanovsky and reviewed by Meloë Kacenelenbogen and two anonymous referees.

\section{References}

ACEPOL Science Team: Aerosol Characterization from Polarimeter and Lidar Campaign, NASA Langley Atmospheric Science Data Center DAAC, https://doi.org/10.5067/SUBORBITAL/ACEPOL2017/DATA001, 2017.

AirMSPI Science Team: Aerosol Characterization from Polarimeter and Lidar Campaign, AirMSPI instrument ellipsoid mapped data, NASA Langley Atmospheric Science Data Center DAAC,
https://doi.org/10.5067/AIRCRAFT/AIRMSPI/ACEPOL/ RADIANCE/ELLIPSOID_V006, 2017a.

AirMSPI Science Team: Aerosol Characterization from Polarimeter and Lidar Campaign, AirMSPI instrument terrain mapped data, NASA Langley Atmospheric Science Data Center DAAC, https://doi.org/10.5067/AIRCRAFT/AIRMSPI/ACEPOL/ RADIANCE/ELLIPSOID_V006, 2017b.

Alexandrov, M. D., Cairns, B., Emde, C., Ackerman, A. S., and van Diedenhoven, B.: Accuracy assessments of cloud droplet size retrievals from polarized reflectance measurements by the research scanning polarimeter, Remote Sens. Environ., 125, 92111, https://doi.org/10.1016/j.rse.2012.07.012, 2012a.

Alexandrov, M. D., Cairns, B., and Mishchenko, M. I.: Rainbow fourier transform, J. Quant. Spectrosc. Ra., 113, 2521-2535, 2012 b.

Alexandrov, M. D., Cairns, B., Wasilewski, A. P., Ackerman, A. S., McGill, M. J., Yorks, J. E., Hlavka, D. L., Platnick, S. E., Arnold, G. T., van Diedenhoven, B., Chowdhary, J., Ottaviani, M., and Knobelspiesse, K. D.: Liquid water cloud properties during the Polarimeter Definition Experiment (PODEX), Remote Sens. Environ., 169, 20-36, https://doi.org/10.1016/j.rse.2015.07.029, 2015.

Alexandrov, M. D., Cairns, B., Sinclair, K., Wasilewski, A. P., Ziemba, L., Crosbie, E., Moore, R., Hair, J., Scarino, A. J., Hu, Y., Stamnes, S., Shook, M. A., and Chen, G.: Retrievals of cloud droplet size from the research scanning polarimeter data: Validation using in situ measurements, Remote Sens. Environ., 210, 76-95, https://doi.org/10.1016/j.rse.2018.03.005, 2018.

Berg, L. K., Fast, J. D., Barnard, J. C., Burton, S. P., Cairns, B., Chand, D., Comstock, J. M., Dunagan, S., Ferrare, R. A., Flynn, C. J., Hair, J. W., Hostetler, C. A., Hubbe, J., Jefferson, A., Johnson, R., Kassianov, E. I., Kluzek, C. D., Kollias, P., Lamer, K., Lantz, K., Mei, F., Miller, M. A., Michalsky, J., Ortega, I., Pekour, M., Rogers, R. R., Russell, P. B., Redemann, J., Sedlacek III, A. J., Segal-Rosenheimer, M., Schmid, B., Shilling, J. E., Shinozuka, Y., Springston, S. R., Tomlinson, J. M., Tyrrell, M., Wilson, J. M., Volkamer, R., Zelenyuk, A., and Berkowitz, C. M.: The Two-Column Aerosol Project: Phase I - Overview and impact of elevated aerosol layers on aerosol optical depth, J. Geophys. Res.-Atmos., 121, 336-361, https://doi.org/10.1002/2015JD023848, 2016.

Boucher, O., Randall, D., Artaxo, P., Bretherton, C., Feingold, G., Forster, P., Kerminen, V.-M., Kondo, Y., Liao, H., Lohmann, U., Rasch, P., Satheesh, S. K., Sherwood, S., Stevens, B., and Zhang, X. Y.: Clouds and Aerosols inClimate Change 2013 - The Physical Science Basis, in: Contribution of the Working Group I to the Fifth Assessment Report of the IPCC, edited by: Stocker, T. F., Qin, D., Plattner, G.-K., Tignor, M., Allen, S. K., Boschung, J., Nauels, A., Xia, Y., Bex, V., and Midgley, P. M., Cambridge University Press, New York, NY, 2013.

Bruegge, C. J., Halthore, R. N., Markham, B., Spanner, M., and Wrlgley, R.: Aerosol optical depth retrievals over the Konza Prairie, J. Geophys. Res.-Atmos., 97, 18743-18758, 1992.

Bucholtz, A., Hlavka, D. L., McGill, M. J., Schmidt, K. S., Pilewskie, P., Davis, S. M., Reid, E. A., and Walker, A. L.: Directly measured heating rates of a tropical subvisible cirrus cloud, J. Geophys. Res., 115, D00J09, https://doi.org/10.1029/2009JD013128, 2010. 
Burton, S. P., Ferrare, R. A., Hostetler, C. A., Hair, J. W., Kittaka, C., Vaughan, M. A., Obland, M. D., Rogers, R. R., Cook, A. L., Harper, D. B., and Remer, L. A.: Using airborne high spectral resolution lidar data to evaluate combined active plus passive retrievals of aerosol extinction profiles, J. Geophys. Res-Atmos., 115, https://doi.org/10.1029/2009JD012130, 2010.

Burton, S. P., Ferrare, R. A., Hostetler, C. A., Hair, J. W., Rogers, R. R., Obland, M. D., Butler, C. F., Cook, A. L., Harper, D. B., and Froyd, K. D.: Aerosol classification using airborne High Spectral Resolution Lidar measurements - methodology and examples, Atmos. Meas. Tech., 5, 73-98, https://doi.org/10.5194/amt-5-732012, 2012.

Burton, S. P., Ferrare, R. A., Vaughan, M. A., Omar, A. H., Rogers, R. R., Hostetler, C. A., and Hair, J. W.: Aerosol classification from airborne HSRL and comparisons with the CALIPSO vertical feature mask, Atmos. Meas. Tech., 6, 13971412, https://doi.org/10.5194/amt-6-1397-2013, 2013.

Burton, S. P., Hostetler, C. A., Cook, A. L., Hair, J. W., Seaman, S. T., Scola, S., Harper, D. B., Smith, J. A., Fenn, M. A., Ferrare, R. A., Saide, P. E., Chemyakin, E. V., and Müller, D.: Calibration of a high spectral resolution lidar using a Michelson interferometer, with data examples from ORACLES, Appl. Optics, 57, 60616075, 2018.

da Silva, A., Maring, H., Seidel, F., Behrenfeld, M., Ferrare, R., and Mace, G.: Aerosol, Cloud and Ecosystems (ACE) Final Report, NASA, available at: https://acemission. gsfc.nasa.gov/documents/ACE-Final-Report-Redacted.pdf (last access: 3 September 2020), 2019.

Diner, D., Davis, A., Hancock, B., Geier, S., Rheingans, B., Jovanovic, V., Bull, M., Rider, D., Chipman, R., Mahler, A., and McClain, S.: First results from a dual photoelastic-modulatorbased polarimetric camera, Appl. Optics, 49, 2929-2946, 2010.

Diner, D. J., Garay, M. J., Kalashnikova, O. V., Rheingans, B. E., Geier, S., Bull, M. A., Jovanovic, V. M., Xu, F., Bruegge, C. J., Davis, A., Crabtree, K., and Chipman, R. A.: Airborne multiangle spectropolarimetric imager (AirMSPI) observations over California during NASA's polarimeter definition experiment (PODEX), in: Polarization Science and Remote Sensing VI 8897), SPIE, 2013a.

Diner, D. J., Xu, F., Garay, M. J., Martonchik, J. V., Rheingans, B. E., Geier, S., Davis, A., Hancock, B. R., Jovanovic, V. M., Bull, M. A., Capraro, K., Chipman, R. A., and McClain, S. C.: The Airborne Multiangle SpectroPolarimetric Imager (AirMSPI): a new tool for aerosol and cloud remote sensing, Atmos. Meas. Tech., 6, 2007-2025, https://doi.org/10.5194/amt-6-2007-2013, $2013 b$.

Diner, D. J., Boland, S. W., Brauer, M., Bruegge, C., Burke, K. A., Chipman, R., Girolamo, L. D., Garay, M. J., Hasheminassab, S., Hyer, E., Jerrett, M., Jovanovic, V., Kalashnikova, O. V., Liu, Y., Lyapustin, A. I., Martin, R. V., Nastan, A., Ostro, B. D., Ritz, B., Schwartz, J., Wang, J., and Xu, F.: Advances in multiangle satellite remote sensing of speciated airborne particulate matter and association with adverse health effects: from MISR to MAIA, J. Appl. Remote Sens., 12, 1-22, https://doi.org/10.1117/1.JRS.12.042603, 2018.

Di Noia, A., Hasekamp, O. P., van Harten, G., Rietjens, J. H. H., Smit, J. M., Snik, F., Henzing, J. S., de Boer, J., Keller, C. U., and Volten, H.: Use of neural networks in ground-based aerosol retrievals from multi-angle spectropolarimetric observations, At- mos. Meas. Tech., 8, 281-299, https://doi.org/10.5194/amt-8281-2015, 2015.

Dubovik, O., Sinyuk, A., Lapyonok, T., Holben, B. N., Mishchenko, M., Yang, P., Eck, T. F., Volten, H., Muñoz, O., Veihelmann, B., van der Zande, W. J., Leon, J.-F., Sorokin, M., and Slutsker, I.: Application of spheroid models to account for aerosol particle nonsphericity in remote sensing of desert dust, J. Geophys. ResAtmos., 111, https://doi.org/10.1029/2005JD006619, 2006.

Dubovik, O., Herman, M., Holdak, A., Lapyonok, T., Tanré, D., Deuzé, J. L., Ducos, F., Sinyuk, A., and Lopatin, A.: Statistically optimized inversion algorithm for enhanced retrieval of aerosol properties from spectral multi-angle polarimetric satellite observations, Atmos. Meas. Tech., 4, 975-1018, https://doi.org/10.5194/amt-4-975-2011, 2011.

Dubovik, O., Li, Z., Mishchenko, M. I., Tanre, D., Karol, Y., Bojkov, B., Cairns, B., Diner, D. J., Espinosa, W. R., Goloub, P., Gu, X., Hasekamp, O., Hong, J., Hou, W., Knobelspiesse, K. D., Landgraf, J., Li, L., Litvinov, P., Liu, Y., Lopatin, A., Marbach, T., Maring, H., Martins, V., Meijer, Y., Milinevsky, G., Mukai, S., Parol, F., Qiao, Y., Remer, L., Rietjens, J., Sano, I., Stammes, P., Stamnes, S., Sun, X., Tabary, P., Travis, L. D., Waquet, F., Xu, F., Yan, C., and Yin, D.: Polarimetric remote sensing of atmospheric aerosols: Instruments, methodologies, results, and perspectives, J. Quant. Spectrosc. Ra., 224, 474-511, https://doi.org/10.1016/j.jqsrt.2018.11.024, 2019.

Ferrec, Y., Bonnery, G., Brooker, L., Croizé, L., Gousset, S., and Le Coarer, E.: NanoCarb part 1: compact snapshot imaging interferometer for $\mathrm{CO}_{2}$ monitoring from space, in: International Conference on Space Optics - ICSO 2018, 1118021, 2019.

Fu, G. and Hasekamp, O.: Retrieval of aerosol microphysical and optical properties over land using a multimode approach, Atmos. Meas. Tech., 11, 6627-6650, https://doi.org/10.5194/amt11-6627-2018, 2018.

Fu, G., Hasekamp, O., Rietjens, J., Smit, M., Di Noia, A., Cairns, B., Wasilewski, A., Diner, D., Seidel, F., Xu, F., Knobelspiesse, K., Gao, M., da Silva, A., Burton, S., Hostetler, C., Hair, J., and Ferrare, R.: Aerosol retrievals from different polarimeters during the ACEPOL campaign using a common retrieval algorithm, Atmos. Meas. Tech., 13, 553-573, https://doi.org/10.5194/amt13-553-2020, 2020.

Gao, M., Zhai, P.-W., Franz, B. A., Knobelspiesse, K., Ibrahim, A., Cairns, B., Craig, S. E., Fu, G., Hasekamp, O., Hu, Y., and Werdell, P. J.: Inversion of multiangular polarimetric measurements from the ACEPOL campaign: an application of improving aerosol property and hyperspectral ocean color retrievals, Atmos. Meas. Tech., 13, 3939-3956, https://doi.org/10.5194/amt13-3939-2020, 2020.

Gimmestad, G., Forrister, H., Grigas, T., and O’Dowd, C.: Comparisons of aerosol backscatter using satellite and ground lidars: implications for calibrating and validating spaceborne lidar, Sci. Rep.-UK, 7, 1-6, 2017.

GroundMSPI Science Team: Aerosol Characterization from Polarimeter and Lidar Campaign, GroundMSPI instrument data, NASA Langley Atmospheric Science Data Center DAAC, https://doi.org/10.5067/GROUND/GROUNDMSPI/ ACEPOL/RADIANCE_v009, 2017.

Hair, J. W., Hostetler, C. A., Cook, A. L., Harper, D. B., Ferrare, R. A., Mack, T. L., Welch, W., Izquierdo, L. R., and Hovis, F. 
E.: Airborne High Spectral Resolution Lidar for profiling aerosol optical properties, Appl. Optics, 47, 6734-6752, 2008.

Hamill, P., Iraci, L. T., Yates, E. L., Gore, W., Bui, T. P., Tanaka, T., and Loewenstein, M.: A new instrumented airborne platform for atmospheric research, B. Am. Meteorol. Soc., 97, 397-404, 2016.

Hasekamp, O. P., Litvinov, P., and Butz, A.: Aerosol properties over the ocean from PARASOL multiangle photopolarimetric measurements, J. Geophys. Res., 116, D14204, https://doi.org/10.1029/2010JD015469, 2011.

Hasekamp, O. P., Fu, G., Rusli, S. P., Wu, L., Noia, A. D., aan de Brugh, J., Landgraf, J., Smit, J. M., Rietjens, J., and van Amerongen, A.: Aerosol measurements by SPEXone on the NASA PACE mission: expected retrieval capabilities, J. Quant. Spectrosc. Ra., 227, 170-184, https://doi.org/10.1016/j.jqsrt.2019.02.006, 2019.

Hlavka, D. L., Yorks, J. E., Young, S. A., Vaughan, M. A., Kuehn, R. E., McGill, M. J., and Rodier, S. D.: Airborne validation of cirrus cloud properties derived from CALIPSO lidar measurements: Optical properties, J. Geophys. Res., 117, D09207, https://doi.org/10.1029/2011JD017053, 2012.

Holben, B. N., Eck, T. F., Slutsker, I., Tanré, D., Buis, J. P., Setzer, A., Vermote, E., Reagan, J. A., Kaufman, Y. J., Nakajima, T., Lavenu, F., Jankowiak, I., and Smirnov, A.: AERONET - A Federated Instrument Network and Data Archive for Aerosol Characterization, Remote Sens. Environ., 66, 1-16, https://doi.org/10.1016/S0034-4257(98)00031-5, 1998.

Kalashnikova, O. V., Garay, M. J., Bates, K. H., Kenseth, C. M., Kong, W., Cappa, C. D., Lyapustin, A. I., Jonsson, H. H., Seidel, F. C., Xu, F., Diner, D. J., and Seinfeld, J. H.: Photopolarimetric Sensitivity to Black Carbon Content of Wildfire Smoke: Results From the 2016 ImPACT-PM Field Campaign, J. Geophys. Res-Atmos., 123, 5376-5396, https://doi.org/10.1029/2017JD028032, 2018.

Knobelspiesse, K., Tan, Q., Bruegge, C., Cairns, B., Chowdhary, J., van Diedenhoven, B., Diner, D., Ferrare, R., van Harten, G., Jovanovic, V., Ottaviani, M., Redemann, J., Seidel, F., and Sinclair, K.: Intercomparison of airborne multi-angle polarimeter observations from the Polarimeter Definition Experiment, Appl. Optics, 58, 650-669, https://doi.org/10.1364/AO.58.000650, 2019.

Kokhanovsky, A. A., Davis, A. B., Cairns, B., Dubovik, O., Hasekamp, O. P., Sano, I., Mukai, S., Rozanov, V. V., Litvinov, P., Lapyonok, T., Kolomiets, I. S., Oberemok, Y. A., Savenkov, S., Martin, W., Wasilewski, A., di Noia, A., Stap, A., Rietjens, J., Xu, F., Natraj, V., Duan, M., Cheng, T., and Munro, R.: SpaceBased Remote Sensing of Atmospheric Aerosols: The MultiAngle Spectro-Polarimetric Frontier, Earth-Sci. Rev., 145, 85116, https://doi.org/10.1016/j.earscirev.2015.01.012, 2015.

Krings, T., Gerilowski, K., Buchwitz, M., Reuter, M., Tretner, A., Erzinger, J., Heinze, D., Pflüger, U., Burrows, J. P., and Bovensmann, H.: MAMAP - a new spectrometer system for column-averaged methane and carbon dioxide observations from aircraft: retrieval algorithm and first inversions for point source emission rates, Atmos. Meas. Tech., 4, 1735-1758, https://doi.org/10.5194/amt-4-1735-2011, 2011.

Lacagnina, C., Hasekamp, O. P., Bian, H., Curci, G., Myhre, G., van Noije, T., Schulz, M., Skeie, R. B., Takemura, T., and Zhang, K.: Aerosol single-scattering albedo over the global oceans: Comparing PARASOL retrievals with AERONET, OMI, and Aero-
Com models estimates, J. Geophys. Res.-Atmos., 120, 98149836, 2015.

Lacagnina, C., Hasekamp, O. P., and Torres, O.: Direct radiative effect of aerosols based on PARASOL and OMI satellite observations, J. Geophys. Res.-Atmos., 122, 2366-2388, 2017.

LeBlanc, S.: Moving Lines: NASA airborne research flight planning tool release (Version v1.21), Zenodo, https://doi.org/10.5281/zenodo.1478126, 2018.

Li, X. and Strahler, A.: Geometric-optical bidirectional reflectance modeling of thediscrete crown vegetation canopy: effect of crown shape and mutual shadowing, IEEE T. Geosci. Remote, 30, 276-292, 1992.

McBride, B. A., Martins, J. V., Barbosa, H. M. J., Birmingham, W., and Remer, L. A.: Spatial distribution of cloud droplet size properties from Airborne Hyper-Angular Rainbow Polarimeter (AirHARP) measurements, Atmos. Meas. Tech., 13, 1777-1796, https://doi.org/10.5194/amt-13-1777-2020, 2020.

McClain, C. R., Feldman, G. C., and Hooker, S. B.: An overview of the SeaWiFS project and strategies for producing a climate research quality global ocean bio-optical time series, Deep-Sea Res. Pt. II, 51, 5-42, 2004.

McGill, M., Hlavka, D., Hart, W., Scott, V. S., Spinhirne, J., and Schmid, B.: Cloud Physics Lidar: instrument description and initial measurement results, Appl. Optics, 41, 3725-3734, https://doi.org/10.1364/AO.41.003725, 2002.

McGill, M. J., Hlavka, D. L., Hart, W. D., Welton, E. J., and Campbell, J. R.: Airborne lidar measurements of aerosol optical properties during SAFARI-2000, J. Geophys. Res.-Atmos., 108, 8493, https://doi.org/10.1029/2002JD002370, 2003.

McGill, M. J., Hlavka, D. L., Heymsfield, G. M., Li, L., Vaughan, M. A., Tian, L., Racette, P. E., Winker, D. M., and Hart, W. D.: Combined lidar-radar remote sensing: Initial results from CRYSTAL-FACE, J. Geophys. Res., 109, D7, https://doi.org/10.1029/2003JD004030, 2004.

McGill, M. J., Vaughan, M. A., Trepte, C. R., Hart, W. D., Hlavka, D. L., Winker, D. M., and Kuehn, R.: Airborne validation of spatial properties measured by the CALIPSO lidar, J. Geophys. Res., 112, D20201, https://doi.org/10.1029/2007JD008768, 2007.

McGill, M. J., Yorks, J. E., Scott, V. S., Kupchock, A. W., and Selmer, P. A.: The Cloud-Aerosol Transport System (CATS): a technology demonstration on the International Space Station, Proc. SPIE 9612, Lidar Remote Sensing for Environmental Monitoring XV, 96120A, https://doi.org/10.1117/12.2190841, 1 September 2015.

Mishchenko, M. I., Cairns, B., Hansen, J. E., Travis, L. D., Burg, R., Kaufman, Y. J., Vanderlei Martins, J., and Shettle, E. P.: Monitoring of aerosol forcing of climate from space: analysis of measurement requirements, J. Quant. Spectrosc. Ra., 88, 149-161, 2004.

Müller, D., Hostetler, C. A., Ferrare, R. A., Burton, S. P., Chemyakin, E., Kolgotin, A., Hair, J. W., Cook, A. L., Harper, D. B., Rogers, R. R., Hare, R. W., Cleckner, C. S., Obland, M. D., Tomlinson, J., Berg, L. K., and Schmid, B.: Airborne Multiwavelength High Spectral Resolution Lidar (HSRL-2) observations during TCAP 2012: vertical profiles of optical and microphysical properties of a smoke/urban haze plume over the northeastern coast of the US, Atmos. Meas. Tech., 7, 3487-3496, https://doi.org/10.5194/amt-7-3487-2014, 2014. 
National Academies of Sciences, Engineering, and Medicine: Thriving on Our Changing Planet: A Decadal Strategy for Earth Observation from Space, The National Academies Press, Washington, D.C., https://doi.org/10.17226/24938, 2018.

National Research Council: Earth Science and Applications from Space: National Imperatives for the Next Decade and Beyond, The National Academies Press, Washington, D.C., https://doi.org/10.17226/11820, 2007.

Nowottnick, E., Colarco, P., da Silva, A., Hlavka, D., and McGill, M.: The fate of saharan dust across the atlantic and implications for a central american dust barrier, Atmos. Chem. Phys., 11, 8415-8431, https://doi.org/10.5194/acp-11-8415-2011, 2011.

Pauly, R. M., Yorks, J. E., Hlavka, D. L., McGill, M. J., Amiridis, V., Palm, S. P., Rodier, S. D., Vaughan, M. A., Selmer, P. A., Kupchock, A. W., Baars, H., and Gialitaki, A.: Cloud-Aerosol Transport System (CATS) $1064 \mathrm{~nm}$ calibration and validation, Atmos. Meas. Tech., 12, 6241-6258, https://doi.org/10.5194/amt12-6241-2019, 2019.

Platnick, S., Meyer, K. G., King, M. D., Wind, G., Amarasinghe, N., Marchant, B., Arnold, G. T., Zhang, Z., Hubanks, P. A., Holz, R. E., Yang, P., Ridgway, W. L., an d Riedi, J.: The MODIS cloud optical and microphysical products: Collection 6 updates and examples from Terra and Aqua, IEEE T. Geosci. Remote, 55, 502$525,2016$.

Powell, K. A., Hostetler, C. A., Vaughan, M. A., Lee, K.-P., Trepte, C. R., Rogers, R. R., Winker, D. M., Liu, Z., Kuehn, R. E., Hunt, W. H., and Young, S. A.: CALIPSO Lidar Calibration Algorithms. Part I: Nighttime 532-nm Parallel Channel and 532-nm Perpendicular Channel, J. Atmos. Ocean. Tech., 26, 2015-2033, https://doi.org/10.1175/2009JTECHA1242.1, 2009.

Puthukkudy, A., Martins, J. V., Remer, L. A., Xu, X., Dubovik, O., Litvinov, P., McBride, B., Burton, S., and Barbosa, H. M. J.: Retrieval of aerosol properties from Airborne Hyper Angular Rainbow Polarimeter (AirHARP) observations during ACEPOL 2017, Atmos. Meas. Tech. Discuss., https://doi.org/10.5194/amt2020-64, in review, 2020.

Rogers, R. R., Hair, J. W., Hostetler, C. A., Ferrare, R. A., Obland, M. D., Cook, A. L., Harper, D. B., Burton, S. P., Shinozuka, Y., McNaughton, C. S., Clarke, A. D., Redemann, J., Russell, P. B., Livingston, J. M., and Kleinman, L. I.: NASA LaRC airborne high spectral resolution lidar aerosol measurements during MILAGRO: observations and validation, Atmos. Chem. Phys., 9, 4811-4826, https://doi.org/10.5194/acp-9-4811-2009, 2009.

Rogers, R. R., Hostetler, C. A., Hair, J. W., Ferrare, R. A., Liu, Z., Obland, M. D., Harper, D. B., Cook, A. L., Powell, K. A., Vaughan, M. A., and Winker, D. M.: Assessment of the CALIPSO Lidar $532 \mathrm{~nm}$ attenuated backscatter calibration using the NASA LaRC airborne High Spectral Resolution Lidar, Atmos. Chem. Phys., 11, 1295-1311, https://doi.org/10.5194/acp11-1295-2011, 2011.

Rogers, R. R., Vaughan, M. A., Hostetler, C. A., Burton, S. P., Ferrare, R. A., Young, S. A., Hair, J. W., Obland, M. D., Harper, D. B., Cook, A. L., and Winker, D. M.: Looking through the haze: evaluating the CALIPSO level 2 aerosol optical depth using airborne high spectral resolution lidar data, Atmos. Meas. Tech., 7, 4317-4340, https://doi.org/10.5194/amt-7-4317-2014, 2014.

Ross, J.: The radiation regime and architecture of plant stands, Springer, New York, 1981.
Roujean, J. L., Leroy, M., and Deschanps, P. Y.: A bidirectional reflectance model of the Earth's surface for the correction of remote sensing data, J. Geophys. Res., 97, 20455-20468, 1992.

Sawamura, P., Moore, R. H., Burton, S. P., Chemyakin, E., Müller, D., Kolgotin, A., Ferrare, R. A., Hostetler, C. A., Ziemba, L. D., Beyersdorf, A. J., and Anderson, B. E.: HSRL-2 aerosol optical measurements and microphysical retrievals vs. airborne in situ measurements during DISCOVER-AQ 2013: an intercomparison study, Atmos. Chem. Phys., 17, 7229-7243, https://doi.org/10.5194/acp-17-7229-2017, 2017.

Scarino, A. J., Obland, M. D., Fast, J. D., Burton, S. P., Ferrare, R. A., Hostetler, C. A., Berg, L. K., Lefer, B., Haman, C., Hair, J. W., Rogers, R. R., Butler, C., Cook, A. L., and Harper, D. B.: Comparison of mixed layer heights from airborne high spectral resolution lidar, ground-based measurements, and the WRF-Chem model during CalNex and CARES, Atmos. Chem. Phys., 14, 5547-5560, https://doi.org/10.5194/acp-145547-2014, 2014.

Schaaf, C. B., Gao, F., Strahler, A. H., Lucht, W., Li, X., Tsang, T., Strugnell, N. C., Zhang, X., Jin, Y., and Muller, J. P.: First operational BRDF, albedo nadir reflectance products from MODIS, Remote Sens. Environ., 83, 135-148, 2002.

Schaepman-Strub, G., Schaepman, M. E., Painter, T. H., Dangel, S., and Martonchik, J. V.: Reflectance quantities in optical remote sensing: definitions and case studies, Remote Sens. Environ., 103, 27-42, 2006.

Shaw, G. E., Reagan, J. A., and Herman, B. M.: Investigations of atmospheric extinction using direct solar radiation measurements made with a multiple wavelength radiometer, J. Appl. Meteorol., 12, 374-380, 1973.

Sinclair, K., van Diedenhoven, B., Cairns, B., Yorks, J., Wasilewski, A., and McGill, M.: Remote sensing of multiple cloud layer heights using multi-angular measurements, Atmos. Meas. Tech., 10, 2361-2375, https://doi.org/10.5194/amt10-2361-2017, 2017.

Smit, J. M., Rietjens, J. H. H., van Harten, G., Noia, A. D., Laauwen, W., Rheingans, B. E., Diner, D. J., Cairns, B., Wasilewski, A., Knobelspiesse, K. D., Ferrare, R., and Hasekamp, O. P.: SPEX airborne spectropolarimeter calibration and performance, Appl. Optics, 58, 5695-5719, https://doi.org/10.1364/AO.58.005695, 2019.

Snik, F., Karalidi, T., and Keller, C. U.: Spectral modulation for full linear polarimetry, Appl. Optics, 48, 1337-1346, 2009.

Stamnes, S., Hostetler, C., Ferrare, R., Burton, S., Liu, X., Hair, J., Hu, Y., Wasilewski, A., Martin, W., van Diedenhoven, B., Chowdhary, J., Cetinic, I., Berg, L. K., Stamnes, K., and Cairns, B.: Simultaneous polarimeter retrievals of microphysical aerosol and ocean color parameters from the MAPP algorithm with comparison to high-spectral-resolution lidar aerosol and ocean products, Appl. Optics, 57, 2394-2413, https://doi.org/10.1364/AO.57.002394, 2018.

van Diedenhoven, B.: Remote sensing of crystal shapes in ice clouds, in: Springer Series in Light Scattering, Volume 2: Light Scattering, Radiative Transfer and Remote Sensing, edited by: Kokhanovsky, A., Springer International, 197-250, https://doi.org/10.1007/978-3-319-70808-9_5, 2018.

van Diedenhoven, B., Cairns, B., Geogdzhayev, I. V., Fridlind, A. M., Ackerman, A. S., Yang, P., and Baum, B. A.: Remote sensing of ice crystal asymmetry parameter using multi-directional 
polarization measurements - Part 1: Methodology and evaluation with simulated measurements, Atmos. Meas. Tech., 5, 23612374, https://doi.org/10.5194/amt-5-2361-2012, 2012.

van Diedenhoven, B., Cairns, B., Fridlind, A. M., Ackerman, A. S., and Garrett, T. J.: Remote sensing of ice crystal asymmetry parameter using multi-directional polarization measurements Part 2: Application to the Research Scanning Polarimeter, Atmos. Chem. Phys., 13, 3185-3203, https://doi.org/10.5194/acp13-3185-2013, 2013.

van Harten, G., de Boer, J., Rietjens, J. H. H., Di Noia, A., Snik, F., Volten, H., Smit, J. M., Hasekamp, O. P., Henzing, J. S., and Keller, C. U.: Atmospheric aerosol characterization with a ground-based SPEX spectropolarimetric instrument, Atmos. Meas. Tech., 7, 4341-4351, https://doi.org/10.5194/amt-7-43412014, 2014.

van Harten, G., Diner, D. J., Daugherty, B. J. S., Rheingans, B. E., Bull, M. A., Seidel, F. C., Chipman, R. A., Cairns, B., Wasilewski, A. P., and Knobelspiesse, K. D.: Calibration and validation of Airborne Multiangle SpectroPolarimetric Imager (AirMSPI) polarization measurements, Appl. Optics, 57, 44994513, https://doi.org/10.1364/AO.57.004499, 2018.

Vaughan, M., Garnier, A., Josset, D., Avery, M., Lee, K.-P., Liu, Z., Hunt, W., Pelon, J., Hu, Y., Burton, S., Hair, J., Tackett, J. L., Getzewich, B., Kar, J., and Rodier, S.: CALIPSO lidar calibration at $1064 \mathrm{~nm}$ : version 4 algorithm, Atmos. Meas. Tech., 12, 51-82, https://doi.org/10.5194/amt-12-51-2019, 2019.

Vaughan, M. A., Liu, Z., McGill, M. J., Hu, Y., and Obland, M. D.: On the spectral dependence of backscatter from cirrus clouds: Assessing CALIOP's $1064 \mathrm{~nm}$ calibration assumptions using cloud physics lidar measurements, J. Geophys. Res.-Atmos., 115, D14206, https://doi.org/10.1029/2009JD013086, 2010.

Wang, Q., Alappattu, D. P., Billingsley, S., Blomquist, B., Burkholder, R. J., Christman, A. J., Creegan, E. D., de Paolo, T., Eleuterio, D. P., Fernando, H. J. S., Franklin, K. B., Grachev, A. A., Haack, T., Hanley, T. R., Hocut, C. M., Holt, T. R., Horgan, K., Jonsson, H. H., Hale, R. A., Kalogiros, J. A., Khelif, D., Leo, L. S., Lind, R. J., Lozovatsky, I., PlanellaMorato, J., Mukherjee, S., Nuss, W. A., Pozderac, J., Ted Rogers, L., Savelyev, I., Savidge, D. K., Kipp Shearman, R., Shen, L., Terrill, E., Marcela Ulate, A., Wang, Q., Travis Wendt, R., Wiss, R., Woods, R. K., Xu, L., Yamaguchi, R. T., and Yardim, C.: CASPER: Coupled Air-Sea Processes and Electromagnetic Ducting Research, B. Am. Meteorol. Soc., 99, 14491471, https://doi.org/10.1175/BAMS-D-16-0046.1, 2018.

Wanner, W., Li, X., and Strahler, A. H.: On the derivation of kerneldriven models of bidirectional reflectance, J. Geophys. Res., 100, 21077-21090, 1995.
Waquet, F., Léon, J. F., Cairns, B., Goloub, P., Deuzé, J. L., and Auriol, F.: Analysis of the spectral and angular response of the vegetated surface polarization for the purpose of aerosol remote sensing over land, Appl. Optics, 48, 1228-1236, 2009.

Weitkamp, C.: Lidar: range-resolved optical remote sensing of the atmosphere, Springer Science and Business, New York, 2006.

Werdell, P. J., Bailey, S., Fargion, G., Pietras, C., Knobelspiesse, K., Feldman, G., and McClain, C.: Unique data repository facilitates ocean color satellite validation, Eos Trans. AGU, 84, 377-387, 2003.

Werdell, P. J., Behrenfeld, M. J., Bontempi, P. S., Boss, E., Cairns, B., Davis, G. T., Franz, B. A., Gliese, U. B., Gorman, E. T., Hasekamp, O., Knobelspiesse, K. D., Mannino, A., Martins, J. V., McClain, C. R., Meister, G., and Remer, L. A.: The Plankton, Aerosol, Cloud, Ocean Ecosystem Mission: Status, Science, Advances, B. Am. Meteorol. Soc., 100, 1775-1794, https://doi.org/10.1175/BAMS-D-18-0056.1, 2019.

Winker, D. M., Vaughan, M. A., Omar, A., Hu, Y., Powell, K. A., Liu, Z., Hunt, W. H., and Young, S. A.: Overview of the CALIPSO mission and CALIOP data processing algorithms, J. Atmos. Ocean. Tech., 26, 2310-2323, 2009.

Xu, F., van Harten, G., Diner, D. J., Kalashnikova, O. V., Seidel, F. C., Bruegge, C. J., and Dubovik, O.: Coupled retrieval of aerosol properties and land surface reflection using the Airborne Multiangle SpectroPolarimetric Imager, J. Geophys. Res.-Atmos., 122, 7004-7026, https://doi.org/10.1002/2017JD026776, 2017.

Yorks, J. E., Hlavka, D. L., Vaughan, M. A., McGill, M. J., Hart, W. D., Rodier, S., and Kuehn, R.: Airborne validation of cirrus cloud properties derived from CALIPSO lidar measurements: Spatial properties, J. Geophys. Res.-Atmos., 116, D19207, https://doi.org/10.1029/2011JD015942, 2011.

Yorks, J. E., McGill, M. J., Palm, S. P., Hlavka, D. L., Selmer, P. A., Nowottnick, E. P., Vaughan, M. A., Rodier, S. D., and Hart, W. D.: An overview of the CATS level 1 processing algorithms and data products, Geophys. Res. Lett., 43, 4632-4639, https://doi.org/10.1002/2016GL068006, 2016.

Zibordi, G., Mélin, F., Berthon, J.-F., Holben, B., Slutsker, I., Giles, D., D’Alimonte, D., Vandemark, D., Feng, H., Schuster, G., Fabbri, B. E., Kaitala, S., and Seppälä, J.: AERONETOC: A Network for the Validation of Ocean Color Primary Products, J. Atmos. Ocean. Tech., 26, 1634-1651, https://doi.org/10.1175/2009JTECHO654.1, 2009. 